\title{
Comprehensive Sampling of Fourmile Branch and Its Seeplines in the $F$ and $H$ Area of SRS: June 1996 and March 1997
}

\author{
by \\ J. Koch \\ Westinghouse Savannah River Company \\ Savannah River Site \\ Aiken, South Carolina 29808 \\ K. Dixon
}

This paper was prepared in connection with work done under the above contract number with the U. S. Department of Energy. By acceptance of this paper, the publisher and/or recipient acknowledges the U.S. Government's right to retain a nonexclusive, royalty-free license in and to any copyright covering this paper, along with the right to reproduce and to authorize others to reproduce all or part of the copyrighted paper. 
WSRC-TR-98-00287

August 12, 1998

\section{Comprehensive Sampling of Fourmile Branch and Its Seeplines in the F and H Areas of SRS: June 1996, and March 1997 (U)}

Prepared by:

J. W. Koch II and K. L. Dixon

Environmental Analysis Section

Approved by:

J.B. Gladden, Section Manager

Environmental Analysis Section

Westinghouse Savannah River Company

Savannah River Site

Aiken SC 29808

Prepared for the U. S. Department of Energy under contract no. DE-

AC09-96SR 18500 


\section{DISCLAIMER}

\section{Portions of this document may be illegible in electronic image products. Images are produced from the best available original document.}




Disclaimer
This report was prepared as an account of work sponsored by an
agency of the United States Government. Neither the United States
government nor any agency thereof, nor any of their employees,
makes any warranty, expressed or implied, or assumes any legal
liability of responsibility for the accuracy, completeness, of
usefulness of and information, apparatus, product, of process
disclosed, or represents that its use would not infringe privately
owned rights. Reference herein to any specific commercial product,
process, or service by trade name, trademark, manufacturer, or
otherwise does not necessarily constitute or imply its endorsement,
recommendation, or favoring by the United States Government or
any agency thereof. The views and opinions of authors expressed
herein do not necessarily state or reflect those of the United States
Government or any agency thereof.


This page intentionally left blank 
WSRC-TR-98-00287

August 12, 1998

\section{Comprehensive Sampling of Fourmile Branch and Its Seeplines in the F and H Areas of SRS: June 1996, and March 1997 (U)}

Prepared by:

J. W. Koch II and K. L. Dixon

Prepared for the U. S. Department of Energy under contract no. DE-AC09-96SR18500 


\section{Contents}

Executive Summary _ 10

Introduction___ 11

Methods__ 15

Sampling Locations ___ 15

Sample Collection Procedures __ 16

Seepline Water 116

Stream Water Sampling __ 17

Sample Processing __ 17

Discussion__ 20

Comparison of Seepline Locations to Background Locations __ 21

Comparison of Stream and Seepline Locations to Established Standards __ 23

Comparison of June 1996 and March 1997 Stream and Seepline Data with March 1989 Data

Stream and Seepline Water Conductivity and $\mathrm{pH} \_26$

Overall Summary, 1989-1997__ 35

References__ 38

Appendix A _ 42

Water Analytical Methods and Detection Limits for General Engineering/Environmental Physics and Weston Analytical/Thermo Nuclear __ 42

Appendix B__ 47

F- and H-Area Seeplines and FMB Comparisons Against Region IV Standards, Background Concentrations, and 1989 Concentrations for Non-Radionuclides __ 47

Appendix C_ 51

F- and H-Area Seeplines and FMB Comparisons Against Region IV Standards, Background Concentrations, and 1989 Concentrations for Radionuclides __ 51

Appendix D__ 54

Statistical Discussion and Equations ____ 54 


\section{List of Figures}

Figure 1. Location of F-Area Seepage Basins, Seepline Sampling Points (FSP), and Fourmile Branch Sampling Points

Figure 2. Location of H-Area Seepage Basins, Seepline Sampling Points (HSP), and Fourmile Branch Sampling Points

Figure 3. Location of Background Sampling Points (BG) 20

Figure 4. Schematic diagram of flow lines after and before closure of Seepage Basins 32

Figure 5. Schematic Diagram of Plume and Rainfall Impacts 33

Figure 6. Rainfall six months prior to sampling (June 1996 Event) and Long-term Average for F-Area weather station 33

Figure 7. Rainfall six months prior to sampling (March 1997 Event) and Long-term Average for F-Area weather station 34 


\section{List of Tables}

Table 1. Summary of Fourmile Branch and Seepline Sampling 18

Table 2. Comparison of FSP and HSP Locations to Background Locations for June 1996

Table 3. Comparison of FSP and HSP Locations to Background Locations for March 1997

Table 4. PDWS, SDWS, and MCL Standards Used in Data Comparisons 27

Table 5. List of Mean Concentration Ranges for Analytes used in Statistical Analysis for June 1996 29

Table 6. List of Mean Concentration Ranges, or Analytes used in Statistical Analysis for March 1997 30

Table 7. Analytes Reported at Concentrations Greater Than Their Method Detection Limit for June 1996 34

Table 8. Analytes Reported at Concentrations Greater Than Their Method Detection Limit for March 1997 37

\section{APPENDIX A TABLES}

Table 9a. Water Analytical Methods and Detection Limits for General Engineering/ Environmental Physics (Radionuclide Indicators and Gamma PHA) 44

Table 9b. Water Analytical Methods and Detection Limits for General Engineering Laboratories, Inc. (Appendix IX Metals and Cyanide) 45

Table 10a. Water Analytical Methods and Detection Limits for Roy F. Weston/ Thermo Nuclear (TNU) (Radionuclide Indicators and Gamma PHA) 46

Table 10b. Water Analytical Methods and Detection Limits for Roy F. Weston, Appendix IX Metals (total recoverable) and Cyanide 47

(Tables continued next page) 


\section{List of Tables (continues)}

\section{APPENDIX B TABLES (NONRADIONUCLIDES 1989-1997)}

Table 11. Constituents in surface water whose $95 \%$ UCI exceeded background measurements at one or more location along the F- and H-Area seeplines and FMB, 1992-1997.

Table 12. Constituents in surface water whose $95 \%$ UCI exceeded PDWS, SDWS, or MCL at one or more location along the F- and H-Area seeplines and FMB, 1989-1997.

Table 13. Constituents in surface water whose 95\% UCI exceeded 1989 measurements at one or more location along the $\mathrm{F}$ - and H-Area seeplines and FMB, 1989-1997.

\section{APPENDIX C TABLES (RADIONUCLIDES 1989-1997)}

Table 14. Radionuclides in surface water whose $95 \%$ UCI exceeded background measurements at one or more location along the F- and H-Area seeplines and FMB, 1989-1997.

Table 15. Radionuclides in surface water whose $95 \%$ UCI exceeded PDWS, SDWS, or MCL at one or more location along the F- and H-Area seeplines and FMB, 1989-1997.

Table 16. Radionuclides in surface water whose 95\% UCI exceeded 1989 measurements at one or more location along the F- and H-Area seeplines and FMB, 1992-1997. 


\section{List of Acronyms}

BG-Background

CFR-Code of Federal Regulations

DCF $^{\circledR}$-Disposable Capsule Filter

DOT-Department of Transportation

EGG-Environmental Groundwater Group

EMS-Environmental Monitoring Section

EPA-Environmental Protection Agency

EPD-Environmental Protection Department

EP-Environmental Physics

ExR-Exploration Resources

FMB-Fourmile Branch

GE-General Engineering

GSA-General Separations Area

LOD-Limit of Detection

MCL-Maximum Contaminant Levels

MDA-Minimum Detectable Activity

PDWS-Primary Drinking Water Standards

PVC-Polyvinyl Chloride

QA-Quality Assurance

QC-Quality Control

SAIC-Science Applications International Corporation

SDWS-Secondary Drinking Water Standards

SRS-Savannah River Site

SRTC-Savannah River Technology Center

TN-Thermo Nuclear

VOA-Volatile Organic Analysis

WA-Weston Analytical 


\title{
Annual Sampling of Fourmile Branch and Its Seeplines in the F and $H$ Areas of SRS: June 1996 and March 1997
}

\author{
J.W. Koch and K.L. Dixon
}

\section{Executive Summary}

In June 1996, and March 1997 water samples were collected from Fourmile Branch (FMB) and its seeplines in the vicinity of the F- and H-Area Seepage basins. These sampling events represent a continuation of a series of semi-annual sampling events, which are now conducted annually and are aimed at characterizing the shallow groundwater outcropping into FMB and its wetlands. In the past, this groundwater has been shown to contain contaminants migrating from the $\mathrm{F}$ - and H-Area Seepage basins. The samples were analyzed for metals listed in Title 40, Code of Federal Regulations (CFR), Part 264, Appendix IX, various radionuclides, and selected inorganic constituents and parameters. Volatile organic compounds were not analyzed for in this sampling event since in previous events they were below detection limits, (ref. Dixon 1993, Dixon and Koch 1995).

Results from both sampling events indicate that the seeplines of $F$ and $H$ Areas and FMB continue to be influenced by contaminants in groundwater originating from the capped seepage basins, but to a lesser degree than in the past. This suggests that the most concentrated portion of the contaminant plume may have flushed from the system.
Contaminant concentrations measured during these two sampling events were compared to background samples collected during these two events and compared to primary drinking water standard (PDWS), secondary drinking water standards (SDWS), and maximum contaminant levels (MCL) enforceable in 1997. Results were also compared to the 1989 baseline measurements at corresponding locations.

Using two separate statistical tests, the concentrations of analytes were compared to background samples. The purpose of the tests was to determine if concentrations of contaminants along the $\mathrm{F}$ - and $\mathrm{H}$-Area seeplines were greater than background concentrations.

Analytes determined to have concentrations significantly greater than background by statistical analysis were:

\begin{tabular}{lll} 
Area & Event & Analyte \\
\hline F seepline & $6 / 96$ & magnesium, nonvolatile beta \\
& $3 / 97$ & $\begin{array}{l}\text { magnesium, gross alpha } \\
\text { H seepline }\end{array}$ \\
& $6 / 96$ & $\begin{array}{l}\text { cobalt-60, gross alpha, } \\
\text { nonvolatile beta }\end{array}$ \\
& $3 / 97$ & copper, magnesium \\
\hline \hline
\end{tabular}


Those contaminants with concentrations greater than the PDWS SDWS or MCL were:

\begin{tabular}{|c|c|c|}
\hline Area & Event & Analyte \\
\hline \multirow[t]{2}{*}{ F seepline } & $6 / 96$ & $\begin{array}{l}\text { aluminum, cadmium, } \\
\text { manganese, nonvolatile beta, Sr- } \\
90, \text { tritium }\end{array}$ \\
\hline & $3 / 97$ & $\begin{array}{l}\text { aluminum, cadmium, gross } \\
\text { alpha, iron, manganese, } \\
\text { nonvolatile beta, } \mathrm{Sr}-90 \text {, tritium }\end{array}$ \\
\hline \multirow[t]{2}{*}{ H seepline } & $6 / 96$ & $\begin{array}{l}\text { aluminum, gross alpha, } \\
\text { iodine- } 129 \text {, manganese, } \\
\text { nonvolatile beta, Sr-90, tritium }\end{array}$ \\
\hline & $3 / 97$ & $\begin{array}{l}\text { aluminum, iron, manganese, } \\
\text { Nonvolatile beta, tritium }\end{array}$ \\
\hline \multirow[t]{2}{*}{ BG } & $6 / 96$ & aluminum, manganese \\
\hline & $3 / 97$ & iron, manganese \\
\hline \multirow[t]{2}{*}{ FMB } & $6 / 96$ & aluminum, manganese, tritium \\
\hline & $3 / 97$ & iron, manganese, Sr-90, tritium \\
\hline
\end{tabular}

Those analytes found to have concentrations greater than the 1989 baseline measurements at one or more location were:

\begin{tabular}{lll} 
Area & Event & \multicolumn{1}{c}{ Analyte } \\
\hline F seepline & $6 / 96$ & gross alpha, zinc \\
& $3 / 97$ & aluminum, chloride \\
H seepline & $6 / 96$ & aluminum \\
& $3 / 97$ & aluminum, chloride \\
Fourmile Branch & $6 / 97$ & none \\
& $3 / 97$ & Cs-137 \\
\hline
\end{tabular}

There is a problem with "false positive" analytical results for certain metals and radionuclides within this report. A "false positive" analytical results is an analytical result that indicates a certain analyte is present when it actually isn't. "False positive results can arise for a variety of reasons. Specific information regarding false positive results can be obtained by contacting WSRC/EMS. The following provides the relative incident or probability of false positive occurrence for given analytes for each sampling event as noted by EMS.

\section{Metals (March 1997, and previous)}

- High probability (arsenic, antimony, cadmium, selenium)

- Moderate/low probability (cobalt, copper, lead, nickel, silver, thallium, zinc)

$\underline{\text { Radionuclides (June } 1996 \text { and previous }}$ events)

- High probability (Americium-234, Cobalt-57, Cesium-135, Europium155, Iodine-129, Maganese-54, Sodium-22, Nickle-63, Neptunium239, Promethium-144,146,\&147, Antimony-124,\&125, Tin-113, Radium-228, Ruthenium-106, Technetium-99, Thorium-234, Yttrium-88, Zinc-65, Zirconium-95)

- Moderate probability (Americium241, Curium series, Neptunium-237, Plutonium-series, Thorium-230)

- Low probability (Carbon-14, Cobalt60, Cesium-137, tritium, lead-212, Radium-226, Strontium-90, Thorium$228, \& 232$, Uranium series)

\section{Introduction}

The $\mathrm{F}$ and $\mathrm{H}$-Area seepage basins (FHSB) consist of seven seepage basins located within the General Separations Area of the SRS (Figure 1). The basins, which occupy approximately 23 acres have been covered with impermeable clay caps and closed 
under RCRA authority. The nearest stream, Fourmile Branch, is located approximately $1300 \mathrm{ft}$ from the H-Area basins and approximately $1970 \mathrm{ft}$ from the F-Area basins. The FHSB consists of two principal areas: (1) the western area which contains the three F-Area seepage basins and (2) the eastern area which contains four H-Area seepage basins. The F-Area basins cover approximately 7 acres whereas the H-Area basins cover approximately 16 acres. The $\mathrm{F}$ - and $\mathrm{H}$ Area seepage basins were constructed and began operations in 1955. The F-Area seepage basins consisted of three unlined basins that were hydraulically connected by vitrified clay process sewers. The seepage basins received process wastewater from the F-Area Separations Facilities for a period of 33 years. The major sources of waste were cooling water from tritium facilities, nitric acid recovery overheads, general purpose evaporator overheads, and retention basin transfers (Killian et al., 1987a). Other relatively mobile radionuclides introduced into the basins via the waste effluent were ${ }^{90} \mathrm{Sr}$, ${ }^{99} \mathrm{Tc}$, and 129I (Looney et al., 1988). Discharges to the basins ceased in November 1988, and closure caps were placed over the basins to minimize infiltration through the basin sediments in 1990. The H-Area Seepage basins also consisted of three unlined basins that were constructed in 1955. In 1962, however, one basin was made inactive and replaced by a fourth basin. The basins received process wastewater from the H-Area Separations Facilities until 1988. The main sources of waste water included those listed for the F-Area Seepage basins, overheads from the two H-Area Tank
Farm evaporators, and liquids from the Receiving Basin for Offsite Fuels Facility (Killian et al., 1987b). Discharges to the basins terminated in November 1988. Closure caps were placed over the seepage basins in 1991 to minimize infiltration through the basin sediments

In 1988 and 1989, the Savannah River Technology Center (SRTC) (formally Savannah River Laboratory) conducted an extensive study aimed at characterizing the shallow groundwater outcropping into FMB and its associated seeplines (Looney et al., 1988, Haselow et al., 1990). These studies were prompted by observed vegetation stress and tree dieback in relatively small isolated areas of the wetlands on the northern side of FMB.

Looney et al. (1988) collected water samples from upstream and downstream locations on FMB and from its associated seeplines in suspect areas. The samples were analyzed for a wide range of nonradioactive parameters including selected metals, inorganic constituents and parameters, $\mathrm{pH}$, conductivity, and nitrate/nitrite. Results from the analysis of the seepline water suggested the following:

- Sodium, nitrate, and hydrogen ions had reached the seepline from the basins and were affecting the bulk chemistry of the seepline water.

- Several constituents (aluminum, calcium, copper, etc.) were leaching from the soil due to the low $\mathrm{pH}$ shallow groundwater. 
- Cadmium in $\mathrm{F}$ Area and nitrate in both $\mathrm{F}$ and $\mathrm{H}$ Areas were elevated above the PDWS.

- FMB was impacted by constituents (primarily nitrate and sodium) from either the seepline water or local outfalls.

Looney et al. (1988) concluded that these factors, combined with the flooding of previously dry areas resulting from basin operations, were primarily responsible for the observed vegetation stress in the seepline areas and suggested that a more extensive study be performed to further characterize the occurrence of particular analytes in the stream and seepline water.

Subsequently, Leblanc and Loehle (1990) collected cores from trees adjacent to the dieback areas, along with cores from trees in unaffected areas along the F-and $\mathrm{H}$ Area Seeplines for tree ring analysis and chemical analysis. The purpose of the study was to determine, using tree ring analysis, the historical development of forest decline in the dieback areas, and to identify relationships between climatic stresses and growth decline. Chemical analyses were also performed on dated wood samples to determine any relationships between altered soil chemistry and growth decline. Positive growth correlations with rainfall were found to exist and flooding was subsequently ruled out as a cause of tree stress. Leblanc and Loehle (1990) suggested that drought affected both the trees adjacent to the dieback areas, and those from unaffected areas; however, those near dieback areas were slower to recover and concluded that aluminum, sodium, acidity, and heavy metal pollution, with drought acting as a trigger, were the primary causes of the vegetation stress and tree dieback.

Haselow et al. (1990) collected soil cores and stream and seepline water samples from FMB and its seeplines in 1988 and 1989 as a follow-up to the Looney et al. (1988) study. These samples were analyzed for both radioactive and nonradioactive parameters. Between the 1988 and 1989 sampling events, an extensive survey for tritium, $\mathrm{pH}$, and conductivity was conducted along the seeplines. Dixon and Rogers (1993) and Dixon and Koch (1995) reported that results from these studies suggested the following:

- Cadmium and nitrate concentrations along the F-Area Seepline and nitrate concentrations along the H-Area Seepline were above PDWS.

- Manganese and iron concentrations were above the SDWS along both the F- and HArea Seeplines.

- Aluminum and sodium concentrations were elevated along both the $\mathrm{F}$ - and $\mathrm{H}$ Area Seeplines when compared to background concentrations, although no standard existed for further comparison.

- Gross alpha, nonvolatile beta, tritium, ${ }^{241} \mathrm{Am},{ }^{129} \mathrm{I},{ }^{226} \mathrm{Ra},{ }^{89} \mathrm{Sr},{ }^{90} \mathrm{Sr}$, and $233 / 234 \mathrm{U}$ were elevated above the proposed or established drinking water standard at one or more points along the FArea Seepline. 
- Gross alpha, tritium, ${ }^{226} \mathrm{Ra},{ }^{89} \mathrm{Sr}$, and ${ }^{90} \mathrm{Sr}$ were elevated above the proposed or established drinking water standard at one or more points along the H-Area Seepline.

- ${ }^{244} \mathrm{Am},{ }^{60} \mathrm{Co},{ }^{134} \mathrm{Cs}$, and ${ }^{137} \mathrm{Cs}$ had also impacted the seepline but were not above drinking water standards.

- Nonvolatile beta and tritium were above the PDWS in FMB at one or more points.

- Tritium and conductivity were elevated at several points along the F- and H-Area Seeplines.

- Seepline water along the F- and H-Area Seeplines generally exhibited low $\mathrm{pH}$.

- Cadmium, nonvolatile beta, ${ }^{90} \mathrm{Sr}$, $233 / 234 U$, and $238 \mathrm{U}$ in the soil samples were elevated above the SRS background values for soils in at least one sample.

- ${ }^{241} \mathrm{Am},{ }^{244} \mathrm{Cm},{ }^{60} \mathrm{Co},{ }^{129} \mathrm{I}, 238 \mathrm{Pu}$, and ${ }^{226} \mathrm{Ra}$ were also suspected to be above background levels in at least one sample, although no established background data existed for comparison.

These studies confirmed that contaminants migrating from the seepage basins were impacting the water chemistry along the Fand $\mathrm{H}$-Area seeplines.

Releases to the seepage basins were discontinued in 1988 and the basins were capped and sealed in 1990. This was done to slow the release of contaminants to the environment. After the Contaminant plume is diluted and flushed out, the FMB wetland systems below the capped basins should begin to recover.

To monitor temporal changes in the contaminant levels outcropping along the FMB Seepline after closure of the basins, two sampling programs were established. These were the quarterly F- and H-Area tritium survey and a semi-annual sampling program for monitoring metals listed in Title 40 CFR, Part 264, Appendix IX; various inorganics; and selected radionuclides. Results from the tritium surveys, in which tritium, $\mathrm{pH}$, and conductivity are measured at 22 locations along each seepline, have been presented by Dixon and Rogers (1992a and b), Dixon et al., (1994), Rogers and Dixon (1994a,b, and c), and Koch and Dixon (1995, 1996, and 1997). The results of the reported tritium events have shown a significant decrease in tritium concentrations and conductivity values with average $\mathrm{pH}$ values over each of the $\mathrm{F}$ and $\mathrm{H}$ - Area seeplines increasing to more natural ranges ( $\mathrm{pH} 5$ to 6 ) when compared to 1989 . The most recent combined average $\mathrm{pH}$ was reported as 5.5 (Koch and Dixon, 1997). The $\mathrm{pH}$ during the 1989 baseline sampling event was below 4.5. The chronic screening values for $\mathrm{pH}$ are 6.5-9.0 for ecological and 5.0-9.0 for human health.

The objectives of this report are to:

- Present the results from the June 1996 and March 1997 sampling events.

- Compare the June 1996 and March 1997 sampling event results to current established PDWS, SDWS, and MCL standards. 
- Compare the June 1996 and March 1997 sampling event results to the 1989 baseline results.

- Compare the June 1996 and March 1997 sampling event results to the background sample results.

- Make deductions about the transitory changes in contaminant concentrations resulting from basin closures.

- Trend the 1989, 1992, 1993, 1994, 1995, 1996, and 1997 results.

\section{Methods}

A list of organizations involved in these sampling events and their participation is included in the reference section of this report. The analytical laboratories provided all sample containers along with preservatives, blue ice, and coolers necessary to collect and ship the samples. At each location, a sample was collected to measure tritium concentration for Department of Transportation (DOT) shipping clearance. These analyses were performed onsite by EAS technicians at Par Pond laboratory facilities. Lists of the constituents analyzed by each laboratory, along with the methods used and method for a given parameter are shown in Appendix A. A comprehensive listing of the analytical results is given in the Data Summary Reports for these two events (EPD 1997a and b).

\section{Sampling Locations}

FMB stream water samples were collected from three locations and seepline water samples were collected from ten locations as identified in Table 1 and shown on Figures 1, 2, and 3 . Sampling locations were selected in areas that, according to 1989 and 1992 data (Haselow et al., 1990; Dixon and Rogers, 1992a), were being influenced by constituents migrating from the seepage basins. Attempts were also made to establish even sample coverage along both seeplines. Sample locations beginning with the prefix FSP were collected from the F-Area Seepline. Sample locations beginning with the prefix HSP were collected from the $\mathrm{H}$ Area Seepline, and sample locations beginning with the prefix BG were collected from background areas upstream of the GSA. In the event that a sampling location would not yield an adequate volume of water for analysis, the location was listed as a dry hole and no sample was collected. There were no dry holes during either 1996 or 1997 sampling event. Background seepline samples for these sampling events were collected at four locations from areas upstream of the GSA. For Quality Assurance/Quality Control (QA/QC) purposes, duplicate samples were collected at locations and sent to the primary laboratory for analysis. One trip blank sample was carried throughout sampling for each event. The trip blank samples consisted of one of each sample container type filled with deionized water.

These samples were carried to each designated sampling location, handled like the collected samples, and shipped to the analytical laboratories for analyses. 


\section{Sample Collection Procedures}

All sampling events were scheduled during periods of hydraulic stability in order to ensure the collection of representative samples. No samples were collected within three days of 0.25 inches of rainfall. Stream and seepline sampling locations were identified with polyvinyl chloride (PVC) stakes with identification numbers, which served as the sample location ID. Sample locations were identified by area and number. The following area identifiers were used:

- HSP: H-Area Seepline Location

- FSP: F-Area Seepline Location

- FMC: Fourmile Branch Stream Location

- BG: Background Location.

\section{Seepline Water}

The following paragraphs discuss how the sample locations had been prepared prior to beginning the sampling program (1992).

To initially establish a sampling station, a hole was excavated within a three-foot radius of the desired marked location using a clean stainless steel shovel. A five-gallon plastic bucket, screened on the sides and bottom, was placed into the excavated hole and covered with a lid. One such bucket was set at each location, except locations HSP008, HSP043, FSP047 and FSP290 where two buckets were set adjacent one another. A second bucket was needed at these locations to collect sufficient water for duplicate and split samples.
The five-gallon in-ground bucket at location (FSP-012) was relocated approximately 15 feet during the 1996 sampling event because of felled trees and brush in the area. The new location was established as the permanent location for this sample point.

Buckets were bailed one day prior to sample collection using a one-gallon plastic container. Immediately after the buckets were bailed the $\mathrm{pH}$ and conductivity of the water were measured and recorded in the field logbook.

No samples for Volatile Organic Analysis (VOA) were conducted beginning with the June 1996 sampling event since the concentrations of this class of compounds was insignificant or not detected during the previous events, (Dixon and Koch, 1993, 1994).

Using a peristaltic pump powered by a 12-volt battery and equipped with Tygon ${ }^{\circledR}$ tubing, water was pumped from the bucket to the remaining sample containers. New tubing was used for each sampling location and was flushed for 20 seconds with water from the in-ground bucket prior to sample collection

All metals samples for the June 1996 sampling event were filtered through a 0.45 micron or 10 micron membrane, 142 millimeter $(\mathrm{mm})$ diameter, disposable filter to remove fine particulate matter from the sample. The smaller diameter filter was used for stream samples and the 10 micron filter was used for seepline samples. This filtering was performed in the field, away from the sampling locations using portable equipment, 
within four hours of sample collection. To facilitate this, an aliquot of sufficient volume was collected from the sampling location in an unpreserved sample container and transported to the filtering location. All equipment used in filtering the metals samples was dedicated and used only once. A new filter and tubing was used for each sample.

All metals samples for the March 1997 sampling event were filtered at each location by connecting a 10-micron Absolife Disposable Capsule Filter (DCF $\left.{ }^{\circledR}\right)$ to the Tygon ${ }^{\circledR}$ tubing. Discharge from the filter was collected directly into the sample container (Dixon and Cummins, 1994).

\section{Stream Water Sampling}

Collection of the surface water samples was performed by dipping the sample containers directly into the stream water.

Surface grab samples were collected in the middle of the stream from the top of the water column. The container was placed into the water with the mouth facing upstream such that water flowed directly into the container.

All containers were filled to the shoulder with water. Water collected for metals analysis was filtered in the field prior to preservation using the filtering technique employed for the particular sampling event. The filled sample containers were then capped tightly and placed in plastic ziplock bags in coolers and kept cool. The in-situ $\mathrm{pH}$ and conductivity of the stream was measured and recorded in the red field notebook at the time of sampling.

Evidence of sample collection, shipment, and laboratory acceptance and custody prior to sample disposal was documented to ensure sample traceability. Documentation was achieved through a chain-of-custody record that contained the necessary information for individual sample identification and listed the individuals responsible for sample collection, shipment, and receipt along with the necessary signatures and dates.

\section{Sample Processing}

In order to determine the packaging and shipping requirements of specific samples, 25 milliliter (ml) plastic sample containers were filled from selected sample locations and sent to the WSRCPar Pond Laboratory to determine the tritium concentration. Previous total activity analysis revealed that the radioactivity associated with each sample was primarily attributable to tritium in the samples. This is why it was decided to use tritium concentration as the basis for count rates. Locations, which yielded tritium concentrations greater than 1000 picoCuries per milliliter $(\mathrm{pCi} / \mathrm{ml})$ during previous sampling events, were selected for tritium concentration analysis.

If the tritium concentration in the sample for a particular location and sampling event exceeded $2000 \mathrm{pCi} / \mathrm{ml}$, then each sample collected from that location during that event was considered a radioactive sample. Sample packaging and shipping followed applicable procedures. 
Table 1. Summary of Fourmile Branch and Seepline Sampling

\begin{tabular}{|l|l|c|c|c|c|c|}
\hline \multirow{2}{*}{$\begin{array}{l}\text { Sample } \\
\text { Location }\end{array}$} & \multicolumn{2}{l}{ SRS Coordinates } & \multicolumn{1}{c}{ March } & \multicolumn{1}{c|}{ June } & March \\
\hline F Area & FSP012 & 73602 & 49644 & $\boldsymbol{X}$ & $\boldsymbol{X}$ & $\boldsymbol{X}$ \\
\hline & FSP032 & 73367 & 50258 & $\boldsymbol{X}$ & $\boldsymbol{X}$ & $\boldsymbol{X}$ \\
\hline & FSP047 & 73609 & 50607 & $\boldsymbol{X}$ & $\boldsymbol{X}$ & $\boldsymbol{X}$ \\
\hline & FSP204 & 73281 & 48801 & $\boldsymbol{X}$ & $\boldsymbol{X}$ & $\boldsymbol{X}$ \\
\hline & FSP290 & 73160 & 46865 & & $\boldsymbol{X}$ & $\boldsymbol{X}$ \\
\hline H Area & HSP008 & 71005 & 56990 & & $\boldsymbol{X}$ & $\boldsymbol{X}$ \\
\hline & HSP029 & 71278 & 56257 & & $\boldsymbol{X}$ & $\boldsymbol{X}$ \\
\hline & HSP043 & 71644 & 55722 & $\boldsymbol{X}$ & $\boldsymbol{X}$ & $\boldsymbol{X}$ \\
\hline & HSP060 & 71629 & 55190 & & $\boldsymbol{X}$ & $\boldsymbol{X}$ \\
\hline & HSP092 & 72672 & 54129 & & $\boldsymbol{X}$ & $\boldsymbol{X}$ \\
\hline Background & BG001 & 67208 & 59153 & & $\boldsymbol{X}$ & $\boldsymbol{X}$ \\
\hline & BG002 & 67229 & 59363 & & $\boldsymbol{X}$ & $\boldsymbol{X}$ \\
\hline Stream & & & & & & \\
\hline F Area & FMC001F & 72200 & 43900 & & $\boldsymbol{X}$ & $\boldsymbol{X}$ \\
\hline & & & & & & \\
\hline H Area & FMC001H & 70350 & 57050 & $\boldsymbol{X}$ & $\boldsymbol{X}$ & $\boldsymbol{X}$ \\
\hline & FMC002H & 72600 & 53000 & $\boldsymbol{X}$ & $\boldsymbol{X}$ & $\boldsymbol{X}$ \\
\hline Background & BG003 & 67633 & 59281 & & $\boldsymbol{X}$ & $\boldsymbol{X}$ \\
\hline & BG004 & 64723 & 68527 & & $\boldsymbol{X}$ & $\boldsymbol{X}$ \\
\hline
\end{tabular}

$X$ Indicates a Sample was collected 


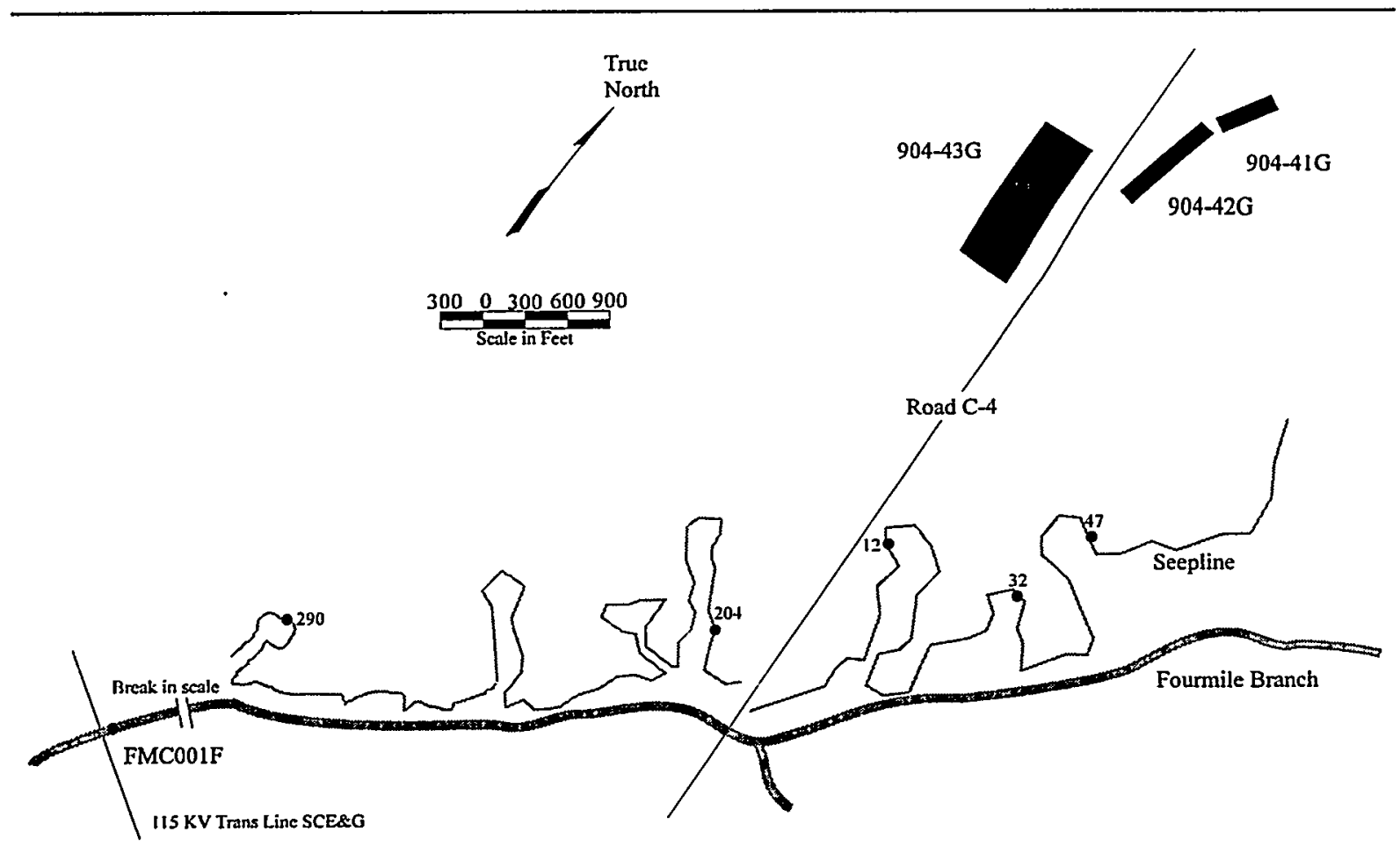

Figure 1. Location of F-Area Seepage Basins, Seepline Sampling Points (FSP), and Fourmile Branch Sampling Points

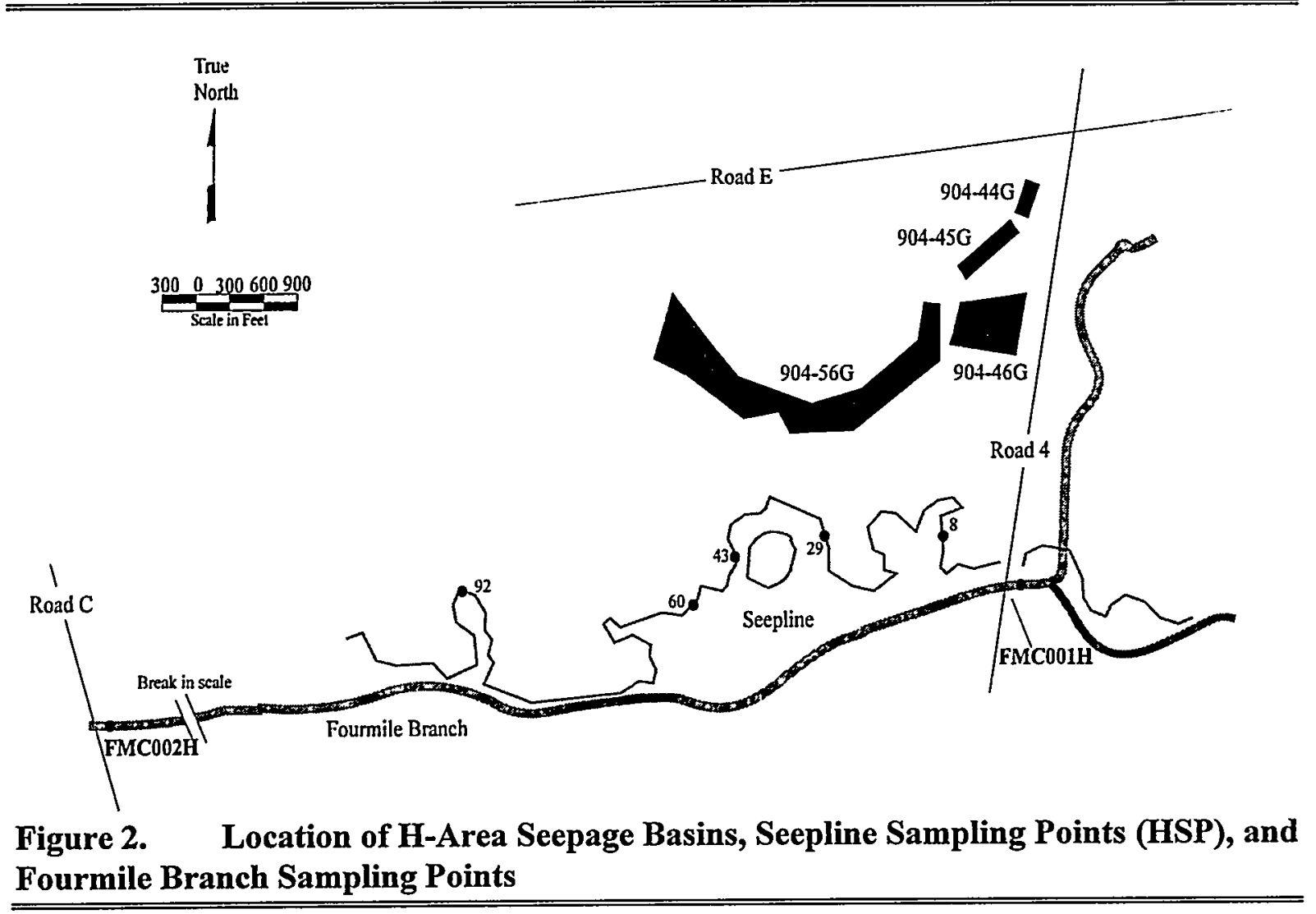




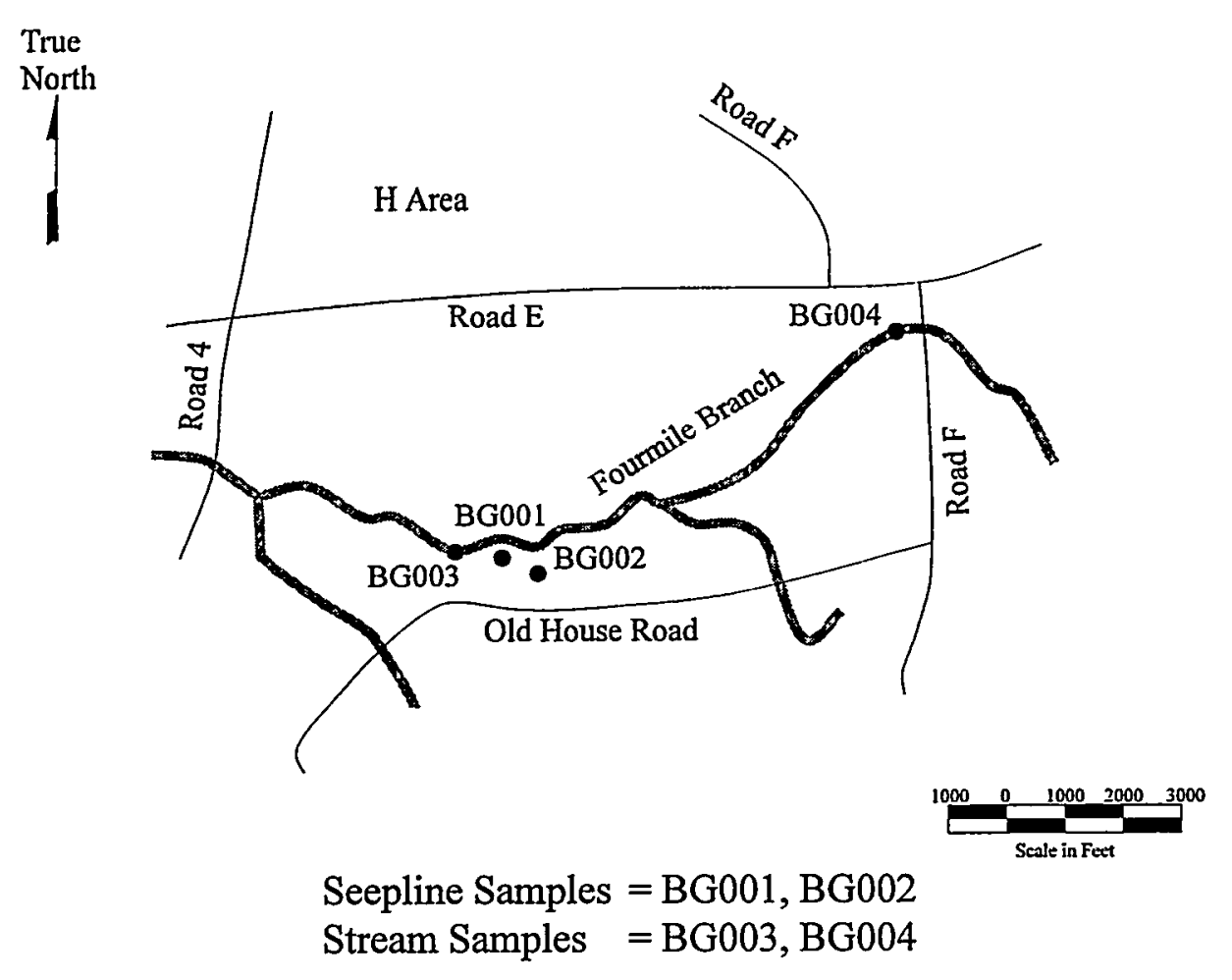

Figure 3. Location of Background Sampling Points (BG)

\section{DISCUSSION}

Concentrations of constituents measured at seepline sampling locations fluctuate throughout the year. Climate, especially rainfall, influences measured concentrations. As discussed in Dixon et al. (1994), seepline measurements are made on water collected from fixed locations at the distal end, or toe, of the contaminant plume. Because the plume is dynamic (i.e., influenced by weather and other activities in the area) seepline monitoring is sensitive to long-term changes and seasonal/transitional influences. Groundwater flow paths in F and $\mathrm{H}$ Area are complex. Recharge to the groundwater is primarily due to infiltration of rainwater (rainfall minus runoff and evapotranspiration). Groundwater then moves laterally toward FMB and its tributaries. As the water travels toward the stream, additional infiltration forces up gradient water deeper. Near the stream, the flow lines rise to the surface, emerging between the seepline and the stream, which acts as the groundwater "drain" (Dixon and Rogers, 1993). This classic vertical trajectory, a path curving downward near the groundwater divide then moving upward into the draining surface water, is shown in the form of flow lines on Figure 4 at the end of this section.

Theoretical flow lines without contribution of contaminated water from the seepage basins are depicted on Figure 4. Figure 4 also depicts theoretical contaminated flow lines resulting from basin operations. The theoretical plume geometry is clearly confirmed by the real vertical profile of the F-Area Seepage Basin plume based on 
the detailed grid wells available in the 1970s (Looney et al., 1993). Changes in the water balance in the area influence the flow velocity and tend to move the plume deeper or shallower and cause the location of the contaminated water to move. This is especially important to data interpretation if the toe of the plume is shifting relative to the fixed sample stations.

Figure 5 summarizes the expected changes in the plume based on a range of transient activities. Increased rainfall (or other activities that increase infiltration, such as harvesting trees) results in increased plume velocity and movement of the plume downward and away from the seepline. This, in turn, results in decreased contaminant concentrations as measured at the seepline sampling locations. Reduction in infiltration, decreases plume velocity and causes movement of the plume upward and closer to the seepline. Consequently, increased contaminant concentrations are measured at the seepline sampling locations (Dixon et al., 1994).

Low rainfall for a few months prior to sampling generally causes an increase in constituent concentrations, and high rainfall causes a decrease in constituent concentrations in the shallow groundwater at the seepline intercept. Figures 6 and 7 compare rainfall data for several months prior to each sampling event to the longterm average. Rainfall during the six months prior to the June 96 sampling event was twenty percent less than the long-term average. This would hypothetically cause the constituent concentrations to be higher. Rainfall prior to the March 1997 sampling event was very close to average minimizing the effects on constituent concentrations at the seepline.

For this report, samples analyzed by the primary laboratory and their subcontractors were considered to be the reference samples on which all analyses and interpretation were based. Samples analyzed by the split laboratory and their subcontractors were considered to be QA samples and were not used in any analyses or interpretations. This should prevent inter-laboratory variability of constituent concentrations from biasing any analyses and interpretations.

Analytical results for both sampling events along FMB and its seeplines are presented in the Data Summary Reports (EPD 1997a $\&$ b). Included in the laboratory analyses table for each analyte is the laboratory that performed the analyses, any analytical modifiers, the analytical result, the accuracy of the result (detected radiological parameters only) and the units in which the results are reported (AN95 format). For locations where split samples were collected, results from each laboratory are presented for each analyte. Laboratory duplicates were averaged with their corresponding reference sample for statistical analysis purposes.

\section{Comparison of Seepline Locations to Background Locations}

Analytical data used in this comparison consisted of the contaminant concentration results from all seepline and background sampling locations. The data was analyzed to determine if contaminant concentrations from each sampling event were 
significantly greater than the same constituent in the background samples.

Frequently, the data were reported by the laboratory as below the Limit of Detection (LOD). Analytical results calculated to be less than the LOD are not considered reliable and therefore are reported as the LOD value. Such data are said to be left censored. Common practice is to include these data in subsequent statistical analyses as LOD/2, which was the method chosen for this comparison. Blind duplicate samples analyzed by GE and EP were also averaged with their corresponding reference samples for statistical analysis. Only non-qualified (other than "U" qualified) data were used for statistical analyses. Analytes were selected for statistical analysis only when $50 \%$ or more of the data in the background or other seepline areas were greater than the LOD. Also, when all background samples were reported as LOD for a particular analyte, no statistical analysis was performed.

A natural $\log$ transformation was performed on the data for the background samples at the two seepline areas (FSP and HSP). Subsequently, a one-way ANOVA was performed on the log-transformed data. The method of single degree of freedom contrasts was used to compare the background mean to each of the two seepline area means. Ranks of the concentration data were also computed and the Mann-Whitney-Wilcoxon same parametric test was performed using these ranks instead of the concentration data. Significance probabilities, or p-values, obtained from each of the single degree of freedom contrasts were examined and compared to the standard Type I error rate criterion of 5\% (i.e., 0.05). However, since these tests were performed on 9 to 15 different chemical constituents measured from the same water sample, a potential for Type I error inflation exist. To protect against such inflation, the Bonferroni multiple comparison method was used. Instead of declaring contrasts among the two pair of seepline means to be significant at the 0.05 level, they were declared significant if their $\mathrm{p}$-values were less than or equal to $0.05 / 9,0.05 / 11$, and $0.05 / 15$ respectively.

Using the parametric ANOVA for the ranks of the concentration data, the following analytes exhibited concentrations significantly greater than background. A complete discussion of the development of the statistics is included in Appendix D.

\begin{tabular}{lll} 
Area & Event & Analyte \\
\hline $\mathrm{F}$ & $6 / 96-$ & magnesium, nonvolatile beta \\
& 3/97- & magnesium, gross alpha \\
$\mathrm{H}$ & $6 / 96-$ & cobalt-60, gross alpha, nonvolatile beta \\
& & \\
& 3/97- & copper, magnesium \\
\hline \hline
\end{tabular}

Using the Mann-Whitney-Wilcoxon test the following analytes exhibited concentrations significantly greater than background.

$\begin{array}{lll}\text { Area } & \text { Event } & \text { Analyte } \\ \text { F } & 6 / 96 & \text { gross alpha } \\ & 3 / 97 & \text { none } \\ \text { H } & 6 / 96 & \text { none } \\ & 3 / 97 & \text { tritium, nitrate-nitrite }\end{array}$

Aluminum, barium, calcium, magnesium, manganese, and potassium are likely being 
leached from the soil profile by low $\mathrm{pH}$ water as suggested by Looney et al. (1988) and Haselow et al. (1990). Observation of the data suggests that the concentrations of these constituents have decreased at most locations for which 1989 measurements were available for comparison. This can be attributed to a general increase in $\mathrm{pH}$ of the seepline water since 1989 (Koch and Dixon, 1996, 1997). An increase in $\mathrm{pH}$ (approximately neutral) will reduce the solubility of these metals and their concentrations in the seepline water. Most F-Area Seepline locations exhibited slightly elevated barium concentrations. The maximum concentration of barium measured at the F-Area Seepline was 407 micrograms per liter $(\mu \mathrm{g} / \mathrm{L})$ well below the MCL of $2000 \mu \mathrm{g} / \mathrm{L}$. Barium concentrations in $\mathrm{H}$ Area did not appear to be elevated above background levels, although tritium and sodium are impacting both seeplines. The general trend, when compared to 1989 concentrations, appears to be toward decline. Results documenting this decline have been presented by Dixon and Rogers (1992a and b, and 1993), (Dixon and Koch 1995), (Koch and Dixon 1995, 1996, 1997).

\section{Comparison of Stream and Seepline Locations to Established Standards}

Table 4 represents the EPA Region IV established human health standards for which the data was compared. Lists of those analytes occurring above LOD are provided in Tables 7 and 8.

Lists of the analytes, along with the corresponding sampling area where concentrations were at levels greater than those established by the PDWS SDWS or $\mathrm{MCL}$, are shown as follows:

\begin{tabular}{|c|c|c|}
\hline Area & Event & Analyte \\
\hline \multirow[t]{2}{*}{ F seepline } & $6 / 96$ & $\begin{array}{l}\text { aluminum, cadmium, manganese, } \\
\text { nonvolatile beta, } \mathrm{Sr}-90 \text {, tritium }\end{array}$ \\
\hline & $3 / 97$ & $\begin{array}{l}\text { aluminum, cadmium, gross alpha, } \\
\text { iron, manganese, nonvolatile beta, } \\
\text { Sr-90, tritium }\end{array}$ \\
\hline \multirow[t]{2}{*}{ H seepline } & $6 / 96$ & $\begin{array}{l}\text { aluminum, gross alpha, I-129, } \\
\text { manganese, nonvolatile beta, } \mathrm{Sr}-90 \text {, } \\
\text { tritium }\end{array}$ \\
\hline & $3 / 97$ & $\begin{array}{l}\text { aluminum, iron, manganese, } \\
\text { nonvolatile beta, tritium }\end{array}$ \\
\hline \multirow[t]{2}{*}{ BG } & $6 / 96$ & aluminum, manganese \\
\hline & $3 / 97$ & iron, manganese \\
\hline \multirow[t]{2}{*}{ FMB } & $6 / 96$ & aluminum, manganese, tritium \\
\hline & $3 / 97$ & iron, manganese,] Sr-90, tritium \\
\hline
\end{tabular}

Eight analytes in June 1996 and eight in March 1997 were found to be above these standards at one or more sampling locations. They included tritium, ${ }^{90} \mathrm{Sr}$, gross alpha, nonvolatile beta, manganese, iron, aluminum, and cadmium.

Six in common analytes (tritium, gross alpha, Sr-90, nonvolatile beta, aluminum, and manganese) were found to be above the PDWS SDWS or the SMCL at one or more seepline and/or stream sampling locations during both sampling events. 
Table 2: Comparison of FSP and HSP Locations to Background Locations for June 1996

\begin{tabular}{|l|c|c|c|c|}
\hline \multirow{2}{*}{} & \multicolumn{2}{c|}{$\begin{array}{c}\text { Natural Log Transform } \\
\text { Contrasts }\end{array}$} & \multicolumn{2}{c|}{ Non-parametric tests } \\
\hline & \multicolumn{2}{|c|}{ AnOVA or Student's t test } & \multicolumn{2}{c|}{ Wilcoxon } \\
\cline { 2 - 5 } Analyte & BG-FSP & BG-HSP & BG-FSP & BG-HSP \\
\hline Arsenic & - & 0.4071 & - & 0.5212 \\
\hline Barium & 0.0538 & 0.1602 & 0.0709 & 0.2148 \\
\hline Cadmium & 0.3739 & - & 0.5345 & - \\
\hline Calcium & 0.5754 & 0.3441 & 0.7228 & 0.4939 \\
\hline Cobalt-60 & - & 0.6485 & - & 1.0000 \\
\hline Copper & 0.3760 & 0.4187 & 0.3460 & 0.3460 \\
\hline Gross alpha & 0.0012 & 0.3704 & 0.1661 & 0.6118 \\
\hline Lead & - & 0.3559 & - & 0.4777 \\
\hline Lead-212 & - & 0.3123 & - & 0.3024 \\
\hline Magnesium & 0.3063 & 0.0418 & 0.4162 & 0.1027 \\
\hline Manganese & 0.1016 & 0.1207 & 0.1500 & 0.2351 \\
\hline Nickel & 0.2123 & - & 0.3174 & - \\
\hline Nonvolatile beta & 0.1832 & 0.0228 & 0.1661 & 0.0998 \\
\hline Sodium & 0.1806 & 0.0250 & 0.2148 & 0.0671 \\
\hline Thallium & - & 0.3559 & - & 0.4777 \\
\hline Vanadium & - & 0.6667 & - & 1.0000 \\
\hline Zinc & 0.5539 & 0.303 & 1.0000 & 0.4370 \\
\hline
\end{tabular}

\section{Comparison of June 1996 and March} 1997 Stream and Seepline Data with March 1989 Data

As previously noted in Table 1, some of the locations sampled during both sampling events were also sampled in 1989. A list of analytes along with the corresponding sampling locations where the subsequent sampling event's concentrations were greater than those measured at the same locations in 1989 is given in the following paragraphs.

In June 1996, three different analytes were measured in at least one sample location at concentrations greater than those measured in 1989 at the same locations. In March
1997, three analytes were also measured at concentrations greater than in 1989. Aluminum was a common analyte exceeding 1989 measurements in both, 1996 and 1997, sampling events.

Compared with the results reported by Dixon and Koch 1995, this was less than one-half the number of analytes earlier found to exceed the 1989 concentrations. 
Table 3: Comparison of FSP and HSP Locations to Background Locations for March 1997

\begin{tabular}{|c|c|c|c|c|}
\hline \multirow{3}{*}{ 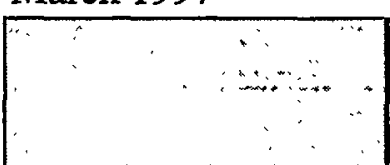 } & \multirow{2}{*}{\multicolumn{2}{|c|}{$\frac{\text { Natural Log Transform Contrasts }}{\text { ANOVA or Student's t test }}$}} & \multirow{2}{*}{\multicolumn{2}{|c|}{$\frac{\text { Non-parametric tests }}{\text { Wilcoxon }}$}} \\
\hline & & & & \\
\hline & BG-FSP & BG-HSP & BG-FSP & BG-HSP \\
\hline Analyte & probe $>|t|$ & probe $>|t|$ & T-Test Prob. & T-Test Prob. \\
\hline Aluminum & 0.4505 & 0.1068 & 0.8893 & 0.2148 \\
\hline Barium & 0.1185 & 0.8486 & 0.2148 & 0.9055 \\
\hline Cadmium & 0.171 & - & 0.2035 & - \\
\hline Calcium & 0.5440 & 0.3138 & 0.4162 & 0.4162 \\
\hline Cesium-137 & - & - & - & - \\
\hline Chloride & 0.5800 & 0.6126 & 0.6780 & 1.0000 \\
\hline Cobalt-60 & - & 0.679 & - & 1.0000 \\
\hline Copper & - & 0.4433 & - & 0.2179 \\
\hline Cyanide & 0.4071 & - & 0.5121 & - \\
\hline Gross alpha & 0.4345 & - & 0.6149 & - \\
\hline Hardness as $\mathrm{CaCO} 3$ & 0.4128 & 0.0969 & 0.6360 & 0.2131 \\
\hline Iron & 0.5718 & 0.7616 & 0.5573 & 0.9055 \\
\hline Lead & - & 0.5415 & - & 0.7381 \\
\hline Lead-212 & 0.2718 & - & 0.3024 & - \\
\hline Magnesium & 0.3521 & 0.4195 & 0.7228 & 0.2148 \\
\hline Manganese & 0.0511 & 0.0482 & 0.1035 & 0.1500 \\
\hline Nickel & 0.0677 & - & 0.1481 & - \\
\hline $\begin{array}{l}\text { Nitrate-nitrite as } \\
\text { nitrogen }\end{array}$ & 0.2150 & 0.0019 & 0.3460 & 0.0484 \\
\hline Nonvolatile beta & 0.2139 & 0.0981 & 0.2994 & 0.2240 \\
\hline Potassium & 0.3938 & 0.0456 & 0.7244 & 0.6026 \\
\hline Potassium-40 & - & 0.7546 & - & 0.7228 \\
\hline Sodium & 0.1582 & 0.0053 & 0.1500 & 0.0484 \\
\hline Tritium & 0.0090 & 0.0002 & 0.0484 & 0.0484 \\
\hline Vanadium & - & 0.6334 & - & 1.0000 \\
\hline Zinc & 0.2584 & - & 0.2367 & - \\
\hline
\end{tabular}


This indicates that, overall; concentrations of analytes appear to be decreasing with time. Further analysis is required to confirm this trend.

Analytes where concentrations exceeded those measured in 1989 at one or more sampling locations included:

\begin{tabular}{lll} 
Area & Event & Analyte \\
\hline F seepline & $6 / 96$ & gross alpha, zinc \\
& $3 / 97$ & aluminum, chloride \\
H seepline & $6 / 96$ & aluminum \\
& $3 / 97$ & aluminum, chloride \\
FMB & $6 / 97$ & none \\
& $3 / 97$ & Cs-137 \\
\hline \hline
\end{tabular}

\section{Stream and Seepline Water Conductivity and $\mathrm{pH}$}

Conductivity and $\mathrm{pH}$ are often used as indicator parameters of overall water quality and can aid the researcher in the overall assessment of the contamination at a site. Conductivity has been particularly useful in delineating areas exhibiting high ion concentrations. The extensive study of $\mathrm{pH}$, conductivity, and tritium in 1989 (Haselow et al., 1990) showed that the seepline water in both $F$ and $H$ Areas exhibited low $\mathrm{pH}$ and high conductivity. Since 1989, quarterly surveys of $\mathrm{pH}$, conductivity, and tritium (Dixon and Rogers, 1992a and b), (Rogers et al), and (Koch and Dixon, 1995, 1996, 1997) have shown that these parameters have been trending toward more normal ranges. The below and above normal $\mathrm{pH}$ measurements during both sampling events were not considered valid since calibrations of $\mathrm{pH}$ instruments used by Rust were not conducted according to established procedures. The $\mathrm{pH}$ of the $\mathrm{F}$ and H-Area Seepline water in the June 1996 sampling event ranged from 2.9 to 5.2 and 4.3 to 5.0 , respectively. This was much lower than has generally been measured during the quarterly and semiannual tritium surveys. The conductivity of the F-and H-Area Seepline water ranged from 23 to 400 micro Seimens per centimeter $(\mu \mathrm{S} / \mathrm{cm})$ and 20 to $230 \mu \mathrm{S} / \mathrm{cm}$, respectively.

The $\mathrm{pH}$ and conductivity of the $\mathrm{pH}$ and conductivity of the background samples ranged from 2.4 to 3.2 and 10 to $30 \mu \mathrm{S} / \mathrm{cm}$ respectively. This $\mathrm{pH}$ was much lower than expected and previously measured at these locations. FMB stream water in June 1996 ranged from 4.4 to 6.3 and 28 to 44 $\mu \mathrm{S} / \mathrm{cm}$.

In March 1997 background $\mathrm{pH}$ and conductivity collectively ranged from 4.6 to 7.2 and 18 to $348 \mu \mathrm{S} / \mathrm{cm}$, respectively. There was one high conductivity measurement unexpected. The $\mathrm{pH}$ measurements for F- and $\mathrm{H}$ - Area Seepline during this same sampling event were from 2.6 to 6.0 and 5.7 to 6.9 , respectively. Conductivity in both seepline areas was typically higher than background. In the $F$ Area, conductivity ranged from 33 to $382 \mu \mathrm{S} / \mathrm{cm}$. In $\mathrm{H}$ Area, conductivity ranged from 33 to 171 $\mu \mathrm{S} / \mathrm{cm}$.

Some seepline $\mathrm{pH}$ values measured appear to be below and some above normal ranges. It is believed that field measurements taken during the tritium sampling events are more reliable. 
Table 4. PDWS, SDWS, and MCL Standards Used in Data Comparisons

\begin{tabular}{|c|c|c|c|c|}
\hline Analyte & Standard & Units & Source & Status \\
\hline Aluminum & 50 & $\mu \mathrm{g} / \mathrm{L}$ & EPA, 1994 & 94-SMCL \\
\hline Americium-241 & $6.34 * *$ & $\mathrm{pCi} / \mathrm{L}$ & EPA, 1991 & Proposed \\
\hline Antimony & 6 & $\mu \mathrm{g} / \mathrm{L}$ & $\overline{\text { EPA, } 1994}$ & 94-MCL \\
\hline Antimony-125 & $300^{* *}$ & $\mathrm{pCi} / \mathrm{L}$ & EPA, 1977 & Final \\
\hline Arsenic & 50 & $\mu \mathrm{g} / \mathrm{L}$ & EPA, 1994 & 94-MCL \\
\hline Barium & 2000 & $\mu \mathrm{g} / \mathrm{L}$ & EPA, 1994 & 94-MCL \\
\hline Benzene & 5 & $\mu \mathrm{g} / \mathrm{L}$ & EPA, 1994 & Final \\
\hline Beryllium & 4 & $\mu \mathrm{g} / \mathrm{L}$ & EPA, 1994 & 94-MCL \\
\hline Cadmium & 5 & $\mu \mathrm{g} / \mathrm{L}$ & EPA, 1994 & 94-MCL \\
\hline Calcium & $\sqrt{\mathrm{NS}}$ & - & F & 1 \\
\hline Cerium-144 & $261 * *$ & $\mathrm{pCi} / \mathrm{L}$ & EPA, 1991 & Proposed \\
\hline Cesium-134 & $81.3^{* *}$ & $\mathrm{pCi} / \mathrm{L}$ & EPA, 1991 & Proposed \\
\hline Cesium-137 & $200^{* *}$ & $\mathrm{pCi} / \mathrm{L}$ & EPA, 1991 & Proposed \\
\hline Chloride & 250 & $\mu \mathrm{g} / \mathrm{L}$ & EPA, 1994 & 94-SMCL \\
\hline Chromium & 100 & $\mu \mathrm{g} / \mathrm{L}$ & EPA, 1994 & 94-MCL \\
\hline Cobalt-57 & $1000^{* *}$ & $\mathrm{pCi} / \mathrm{L}$ & EPA, 1977 & Final \\
\hline Cobalt- 60 & $100^{* * *}$ & $\mathrm{pCi} / \mathrm{L}$ & EPA, 1977 & Final \\
\hline Copper & $1300^{* * *}, \mathrm{tt}$ & $\mu \mathrm{g} / \mathrm{L}$ & EPA, 1994 & 94-MCL \\
\hline Curium-242 & $0.133^{* *}$ & $\mathrm{pCi} / \mathrm{L}$ & EPA, 1991 & Proposed \\
\hline Curium-243,244 & $8.3^{* *}$ & $\mathrm{pCi} / \mathrm{L}$ & EPA, 1991 & Proposed \\
\hline Europium-152 & NS & - & F & I \\
\hline Europium-154 & $200^{* *}$ & $\mathrm{pCi} / \mathrm{L}$ & EPA, 1977 & Final \\
\hline Europium-155 & $600^{* *}$ & $\mathrm{pCi} / \mathrm{L}$ & EPA, 1977 & Final \\
\hline Gross Alpha & 15 & $\mathrm{pCi} / \mathrm{L}$ & EPA, 1994 & 94-MCL \\
\hline Iodine-129 & $11^{* *}$ & $\mathrm{pCi} / \mathrm{L}$ & EPA, 1977 & Final \\
\hline Iron & 300 & $\mu \mathrm{g} / \mathrm{L}$ & EPA, 1994 & 94-SMCL \\
\hline Lead & $15 \mathrm{tt}$ & $\mu \mathrm{g} / \mathrm{L}$ & EPA, 1994 & 94-MCL \\
\hline Magnesium & NS & E & E & 1 \\
\hline Manganese & 50 & $\mu \mathrm{g} / \mathrm{L}$ & EPA, 1994 & 94-SMCL \\
\hline Manganese-54 & $300^{* *}$ & $\mathrm{pCi} / \mathrm{L}$ & EPA, 1977 & Final \\
\hline Mercury & 2 & $\mu \mathrm{g} / \mathrm{L}$ & EPA, 1994 & 94-MCL \\
\hline Neptunium-237 & $7.06 * *$ & $\mathrm{pCi} / \mathrm{L}$ & EPA, 1991 & Proposed \\
\hline Nickel & 100 & $\mu \mathrm{g} / \mathrm{L}$ & EPA, 1994 & 94-MCL \\
\hline Nitrate as nitrogen & 10 & $\mathrm{mg} / \mathrm{L}$ & EPA, 1994 & 94-MCL \\
\hline Nonvolatile Beta & 50 & $\mathrm{pCi} / \mathrm{L}$ & EPA, 1986b & Proposed \\
\hline Plutonium-238 & $7.02 * *$ & $\mathrm{pCi} / \mathrm{L}$ & EPA, 1991 & Proposed \\
\hline Plutonium-239,240 & $62.1^{* *}$ & $\mathrm{pCi} / \mathrm{L}$ & EPA, 1991 & Proposed \\
\hline Potassium & NS & 1 & 5 & - \\
\hline
\end{tabular}


Table 5: List of mean concentrations and ranges for analytes used in statistical analysis for June 1996

\begin{tabular}{|c|c|c|c|c|}
\hline Analyte & Seepline & Units & Mean & Range \\
\hline \multirow[t]{2}{*}{ Aluminum, total recoverable } & FSP & $\mu \mathrm{g} / \mathrm{L}$ & 4730 & $4730-4730$ \\
\hline & HSP & $\mu \mathrm{g} / \mathrm{L}$ & 204 & $204-204$ \\
\hline \multirow[t]{3}{*}{ Barium, total recoverable } & $\mathrm{BG}$ & $\mu \mathrm{g} / \mathrm{L}$ & 22.66 & $9.47-35.60$ \\
\hline & FSP & $\mu \mathrm{g} / \mathrm{L}$ & 111.84 & $26.1-345.0$ \\
\hline & HSP & $\mu \mathrm{g} / \mathrm{L}$ & 45.84 & $22.2-104.0$ \\
\hline \multirow[t]{3}{*}{ Calcium, total recoverable } & $\overline{\mathrm{BG}}$ & $\mu \mathrm{g} / \mathrm{L}$ & 938.75 & $277.0-1590.0$ \\
\hline & FSP & $\mu \mathrm{g} / \mathrm{L}$ & 2673.4 & $465-10700$ \\
\hline & HSP & $\mu \mathrm{g} / \mathrm{L}$ & 3005.25 & $310.0-66950$ \\
\hline Cobalt, total recoverable & FSP & $\mu \mathrm{g} / \mathrm{L}$ & 46.6 & $46.6-46.6$ \\
\hline \multirow[t]{3}{*}{ Gross alpha } & $\overline{B G}$ & $\mathrm{pCi} / \mathrm{L}$ & 1.03 & $0.896-01.33$ \\
\hline & FSP & $\mathrm{pCi} / \mathrm{L}$ & 10.65 & $6.64-14.65$ \\
\hline & HSP & $\mathrm{pCi} / \mathrm{L}$ & 17.09 & $0.282-25.5$ \\
\hline \multirow[t]{3}{*}{ Iodine-129 } & FSP & $\mathrm{pCi} / \mathrm{L}$ & 0.93 & $0.895-0.975$ \\
\hline & HSP & $\mathrm{pCi} / \mathrm{L}$ & 22.20 & $0.855-62.8$ \\
\hline & HSP & $\mathrm{pCi} / \mathrm{L}$ & 4.91 & $2.23-7.88$ \\
\hline \multirow[t]{3}{*}{ Magnesium, total recoverable } & $\mathrm{BG}$ & $\mu \mathrm{g} / \mathrm{L}$ & 489.38 & $315.0-617.0$ \\
\hline & FSP & $\mu \mathrm{g} / \mathrm{L}$ & 1843.3 & $328.5-6800.0$ \\
\hline & HSP & $\mu \mathrm{g} / \mathrm{L}$ & 2114.25 & $542.0-3705.0$ \\
\hline \multirow[t]{3}{*}{ Manganese, total recoverable } & $\overline{B G}$ & $\mu \mathrm{g} / \mathrm{L}$ & 104.75 & $20.2-229.5$ \\
\hline & FSP & $\mu \mathrm{g} / \mathrm{L}$ & 487.14 & $53.7-1380.0$ \\
\hline & HSP & $\mu \mathrm{g} / \mathrm{L}$ & 667.75 & $77.0-1985.0$ \\
\hline \multirow[t]{2}{*}{ Nickel-63 } & FSP & $\mathrm{pCi} / \mathrm{L}$ & 93.77 & $31.2-156.0$ \\
\hline & $\mathrm{HSP}$ & $\mathrm{pCi} / \mathrm{L}$ & 59.23 & $33.175 \quad-84.75$ \\
\hline \multirow[t]{3}{*}{ Nonvolatile beta } & $\mathrm{BG}$ & $\mathrm{pCi} / \mathrm{L}$ & 1.18 & $0.925-1.42$ \\
\hline & FSP & $\mathrm{pCi} / \mathrm{L}$ & 341.95 & $35.90-648.00$ \\
\hline & $\mathrm{HSP}$ & $\mathrm{pCi} / \mathrm{L}$ & 487.5 & $77.5-1230.0$ \\
\hline Radium-226 & HSP & $\mathrm{pCi} / \mathrm{L}$ & 1.59 & $1.585-1.585$ \\
\hline \multirow[t]{3}{*}{ Sodium, total recoverable } & $\mathrm{BG}$ & $\mu \mathrm{g} / \mathrm{L}$ & 1527.25 & $609.0-2500.0$ \\
\hline & FSP & $\mu \mathrm{g} / \mathrm{L}$ & 11139 & $2050-46900$ \\
\hline & $\mathrm{HSP}$ & $\mu \mathrm{g} / \mathrm{L}$ & 21437.5 & $2550-39350$ \\
\hline \multirow[t]{3}{*}{ Strontium-90 } & $\overline{F S P}$ & $\mathrm{pCi} / \mathrm{L}$ & 120.37 & $19.2-313.0$ \\
\hline & HSP & $\mathrm{pCi} / \mathrm{L}$ & 189.93 & $7.61-664.0$ \\
\hline & HSP & $\mathrm{pCi} / \mathrm{L}$ & 20.15 & $10.7-35.0$ \\
\hline
\end{tabular}


Table 5: (continued)

\begin{tabular}{|c|c|c|c|c|}
\hline \multicolumn{2}{|l|}{ Analyte } & Units & $\overline{\text { Mean }}$ & Range \\
\hline \multirow[t]{2}{*}{ Tritium } & FSP & $\mathrm{pCi} / \mathrm{L}$ & 647.4 & $20-2880$ \\
\hline & HSP & $\mathrm{pCi} / \mathrm{L}$ & 630 & $70-1190$ \\
\hline Uranium-233/234 & HSP & $\mathrm{pCi} / \mathrm{L}$ & 1.15 & $0.488-1.82$ \\
\hline \multirow[t]{2}{*}{ Uranium-238 } & HSP & $\mathrm{pCi} / \mathrm{L}$ & 0.31 & $0.156-0.466$ \\
\hline & HSP & $\mathrm{pCi} / \mathrm{L}$ & 12.53 & $5.00-20.05$ \\
\hline \multirow[t]{3}{*}{ Zinc, total recoverable } & $\overline{B G}$ & $\mu \mathrm{g} / \mathrm{L}$ & 5.31 & $5.31-5.31$ \\
\hline & FSP & $\mu \mathrm{g} / \mathrm{L}$ & 36.64 & $5.05-145.0$ \\
\hline & HSP & $\mu \mathrm{g} / \mathrm{L}$ & 6.08 & $5.57-6.58$ \\
\hline
\end{tabular}

Table 6: List of mean concentrations and ranges for analytes used in statistical analysis for March1997

\begin{tabular}{|c|c|c|c|c|}
\hline \multicolumn{5}{|c|}{ Seepline } \\
\hline \multirow[t]{3}{*}{ Aluminum, total recoverable } & BG & $\mu \mathrm{g} / \mathrm{L}$ & 125.89 & $\overline{46.7-229.0}$ \\
\hline & FSP & $\mu \mathrm{g} / \mathrm{L}$ & 3259.44 & $28.25 \quad-212700.00$ \\
\hline & HSP & $\mu \mathrm{g} / \mathrm{L}$ & 979.12 & $87.1-3060.0$ \\
\hline \multirow[t]{3}{*}{ Barium, total recoverable } & $\overline{B G}$ & $\mu \mathrm{g} / \mathrm{L}$ & 22.91 & $9.75-37.3$ \\
\hline & FSP & $\mu \mathrm{g} / \mathrm{L}$ & 120.41 & $17.45-407.00$ \\
\hline & HSP & $\mu \mathrm{g} / \mathrm{L}$ & 22.48 & $17.30-34.60$ \\
\hline \multirow[t]{3}{*}{ Calcium, total recoverable } & $\mathrm{BG}$ & $\mu \mathrm{g} / \mathrm{L}$ & 602.75 & $263.0-1030.0$ \\
\hline & $\overline{\text { FSP }}$ & $\mu \mathrm{g} / \mathrm{L}$ & 2466.70 & $296.5-10200.0$ \\
\hline & HSP & $\mu \mathrm{g} / \mathrm{L}$ & 888.2 & $457-1670$ \\
\hline \multirow[t]{3}{*}{ Chloride } & $\overline{B G}$ & $\mu \mathrm{g} / \mathrm{L}$ & 2882.5 & $1820-3650$ \\
\hline & FSP & $\mu \mathrm{g} / \mathrm{L}$ & 3541.25 & $1870.0-5670.0$ \\
\hline & HSP & $\mu \mathrm{g} / \mathrm{L}$ & 3708 & $2150-7950$ \\
\hline Cobalt, total recoverable & FSP & $\mu \mathrm{g} / \mathrm{L}$ & 58.5 & $58.5-58.5$ \\
\hline Copper, total recoverable & $\overline{\mathrm{HSP}}$ & $\mu \mathrm{g} / \mathrm{L}$ & 2.82 & $1.265000-4.37$ \\
\hline \multirow[t]{3}{*}{ Hardness as $\mathrm{CACO} 3$} & $\mathrm{BG}$ & $\mu \mathrm{g} / \mathrm{L}$ & 4231.25 & $1980-6730$ \\
\hline & FSP & $\mu \mathrm{g} / \mathrm{L}$ & 16505 & $1980-59400$ \\
\hline & HSP & $\mu \mathrm{g} / \mathrm{L}$ & 6899 & $5200-11400$ \\
\hline \multirow[t]{3}{*}{ Iron, total recoverable } & $\overline{\mathrm{BG}}$ & $\mu \mathrm{g} / \mathrm{L}$ & 722 & $106-1070$ \\
\hline & FSP & $\mu \mathrm{g} / \mathrm{L}$ & 609.13 & $53.4-1520.0$ \\
\hline & HSP & $\mu \mathrm{g} / \mathrm{L}$ & \begin{tabular}{|c|}
1201.88 \\
\end{tabular} & $61.9-2390.0$ \\
\hline
\end{tabular}


Table 6: (continued)

\begin{tabular}{|c|c|c|c|c|}
\hline Analyte & Seepline & Units & Mean & Range \\
\hline \multirow[t]{3}{*}{ Magnesium, total recoverable } & $\mathrm{BG}$ & $\mu \mathrm{g} / \mathrm{L}$ & 427.75 & $362.0-522.0$ \\
\hline & FSP & $\mu \mathrm{g} / \mathrm{L}$ & 1699.8 & $235.5-6110.0$ \\
\hline & HSP & $\mu \mathrm{g} / \mathrm{L}$ & 725.9 & $157-1325$ \\
\hline \multirow[t]{3}{*}{ Manganese, total recoverable } & $\overline{\mathrm{BG}}$ & $\mu \mathrm{g} / \mathrm{L}$ & 49.90 & $12.7-108.0$ \\
\hline & FSP & $\mu \mathrm{g} / \mathrm{L}$ & 536.99 & $28.45-1390.0$ \\
\hline & HSP & $\mu \mathrm{g} / \mathrm{L}$ & 114.64 & $75.4-165.5$ \\
\hline Nickel-63 & HSP & $\mathrm{pCi} / \mathrm{L}$ & 191.41 & $50.82-332.00$ \\
\hline Nitrate as nitrogen & HSP & $\mu \mathrm{g} / \mathrm{L}$ & 2090 & $1660-2520$ \\
\hline \multirow[t]{2}{*}{ Nitrate-nitrite as nitrogen } & $\overline{F S P}$ & $\mu \mathrm{g} / \mathrm{L}$ & 15635 & $10-62000$ \\
\hline & HSP & $\mu \mathrm{g} / \mathrm{L}$ & 966 & $410-2600$ \\
\hline \multirow[t]{3}{*}{ Nonvolatile beta } & $\overline{\mathrm{BG}}$ & $\mathrm{pCi} / \mathrm{L}$ & 1.13 & $0.505-1.752$ \\
\hline & FSP & $\mathrm{pCi} / \mathrm{L}$ & 186.84 & $0.5575-680.5$ \\
\hline & HSP & $\mathrm{pCi} / \mathrm{L}$ & 83.98 & $1.6-282$ \\
\hline \multirow[t]{3}{*}{ Potassium, total recoverable } & $\mathrm{BG}$ & $\mu \mathrm{g} / \mathrm{L}$ & 37.88 & $33.05-42.70$ \\
\hline & FSP & $\mu \mathrm{g} / \mathrm{L}$ & 278.36 & $41.72-515$ \\
\hline & HSP & $\mu \mathrm{g} / \mathrm{L}$ & 827 & $827-827$ \\
\hline Radium-228 & FSP & $\mathrm{pCi} / \mathrm{L}$ & 7.37 & $7.37 \quad-7.37$ \\
\hline \multirow[t]{3}{*}{ Sodium, total recoverable } & $\mathrm{BG}$ & $\mu \mathrm{g} / \mathrm{L}$ & 1770.75 & $803-2720$ \\
\hline & FSP & $\mu \mathrm{g} / \mathrm{L}$ & 10282 & $1880-40300$ \\
\hline & HSP & $\mu \mathrm{g} / \mathrm{L}$ & 20780 & $3990-34500$ \\
\hline Strontium-90 & FSP & $\mathrm{pCi} / \mathrm{L}$ & 417.5 & $417.5-417.5$ \\
\hline \multirow[t]{2}{*}{ Technetium-99 } & $\overline{F S P}$ & $\mathrm{pCi} / \mathrm{L}$ & 37.2 & $37.2-37.2$ \\
\hline & HSP & $\mathrm{pCi} / \mathrm{L}$ & 22.96 & $20.92-25.00$ \\
\hline \multirow[t]{3}{*}{ Tritium } & $\mathrm{BG}$ & $\mathrm{pCi} / \mathrm{mL}$ & 2.57 & $1.40-4.41$ \\
\hline & FSP & $\mathrm{pCi} / \mathrm{mL}$ & 558.06 & $16 .-2570.0$ \\
\hline & HSP & $\mathrm{pCi} / \mathrm{mL}$ & 1039.08 & $61.4-2340.0$ \\
\hline
\end{tabular}




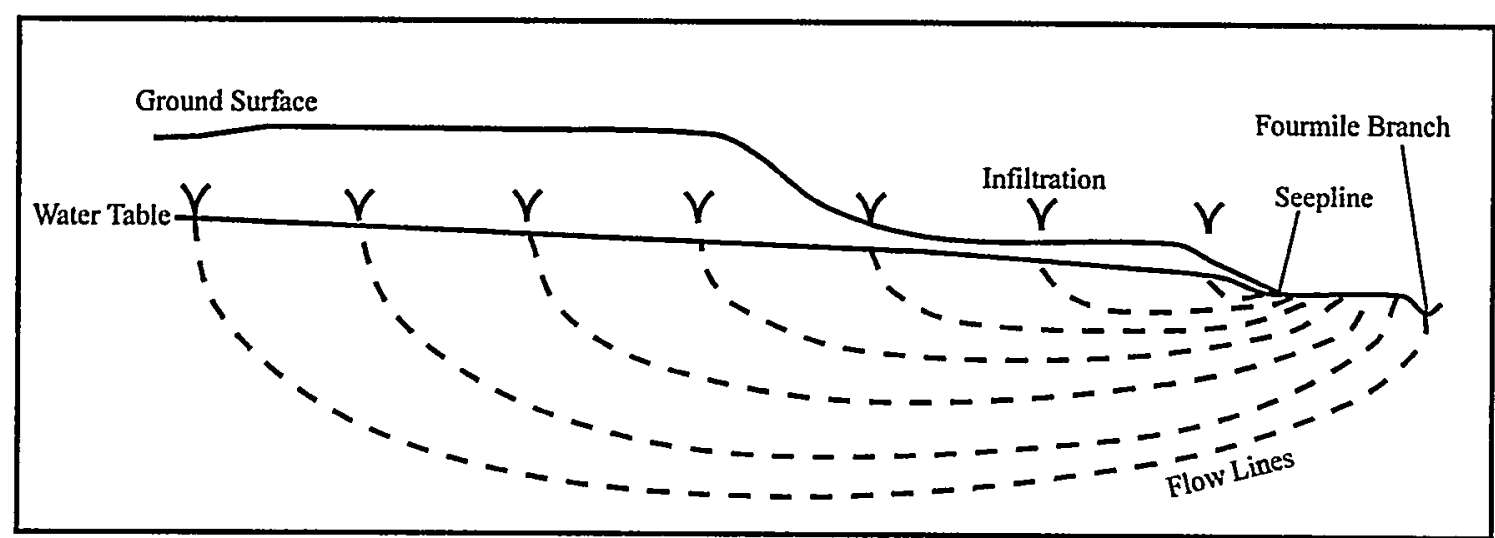

Legend

- Flowline

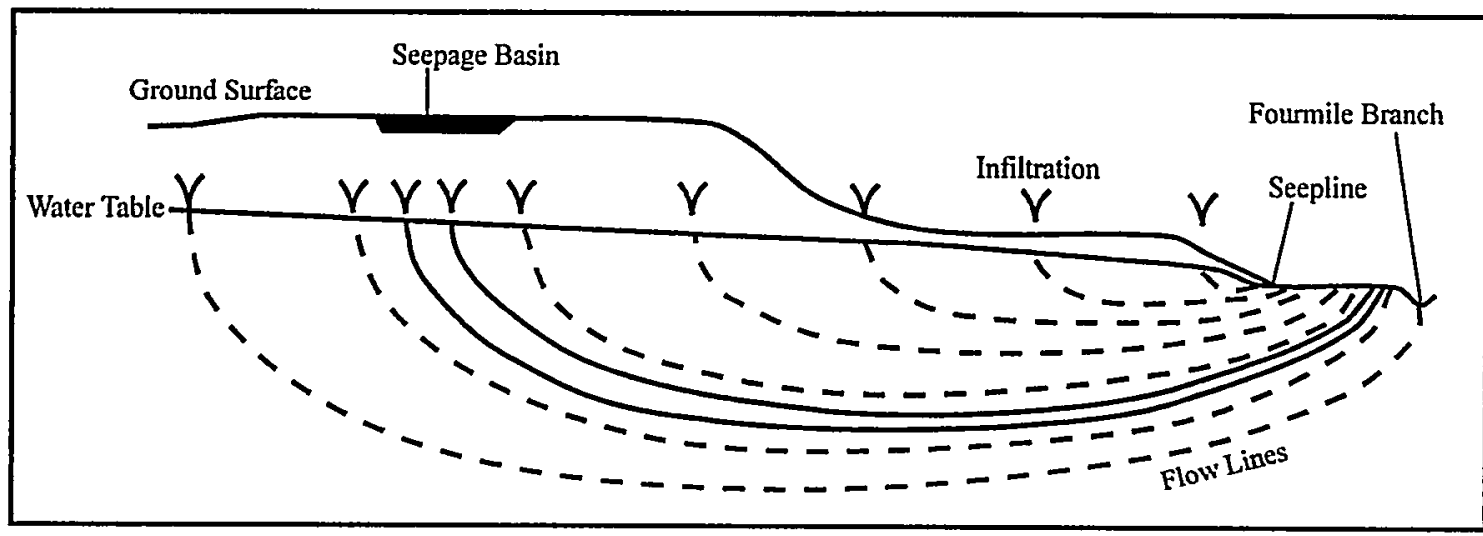

Legend

- Flowline

$\longrightarrow$ Contaminated

Flowline

Figure 4. Schematic diagram of flow lines after and before closure of seepage basins 


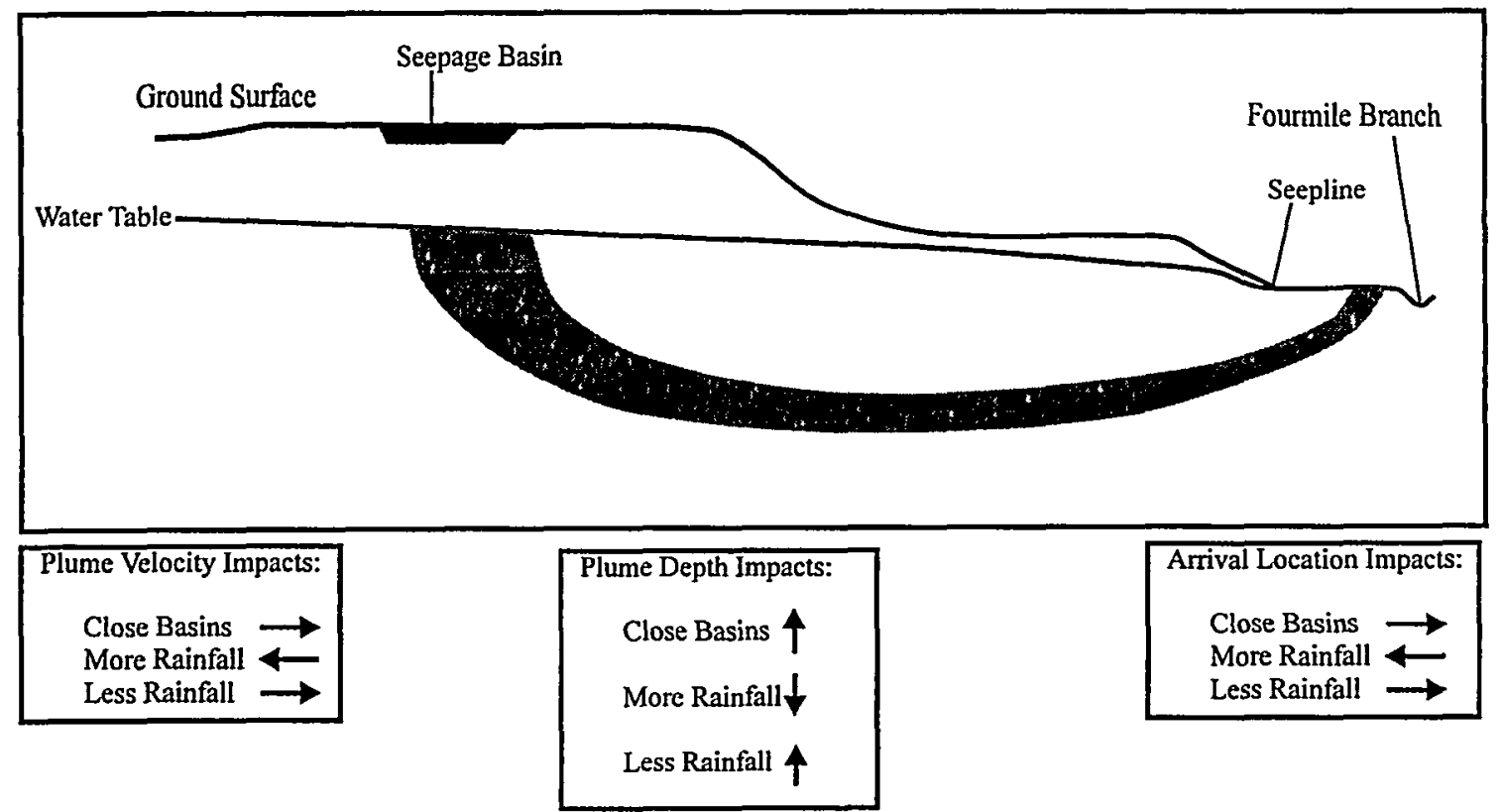

Figure 5. Schematic Diagram of Plume and Rainfall Impacts

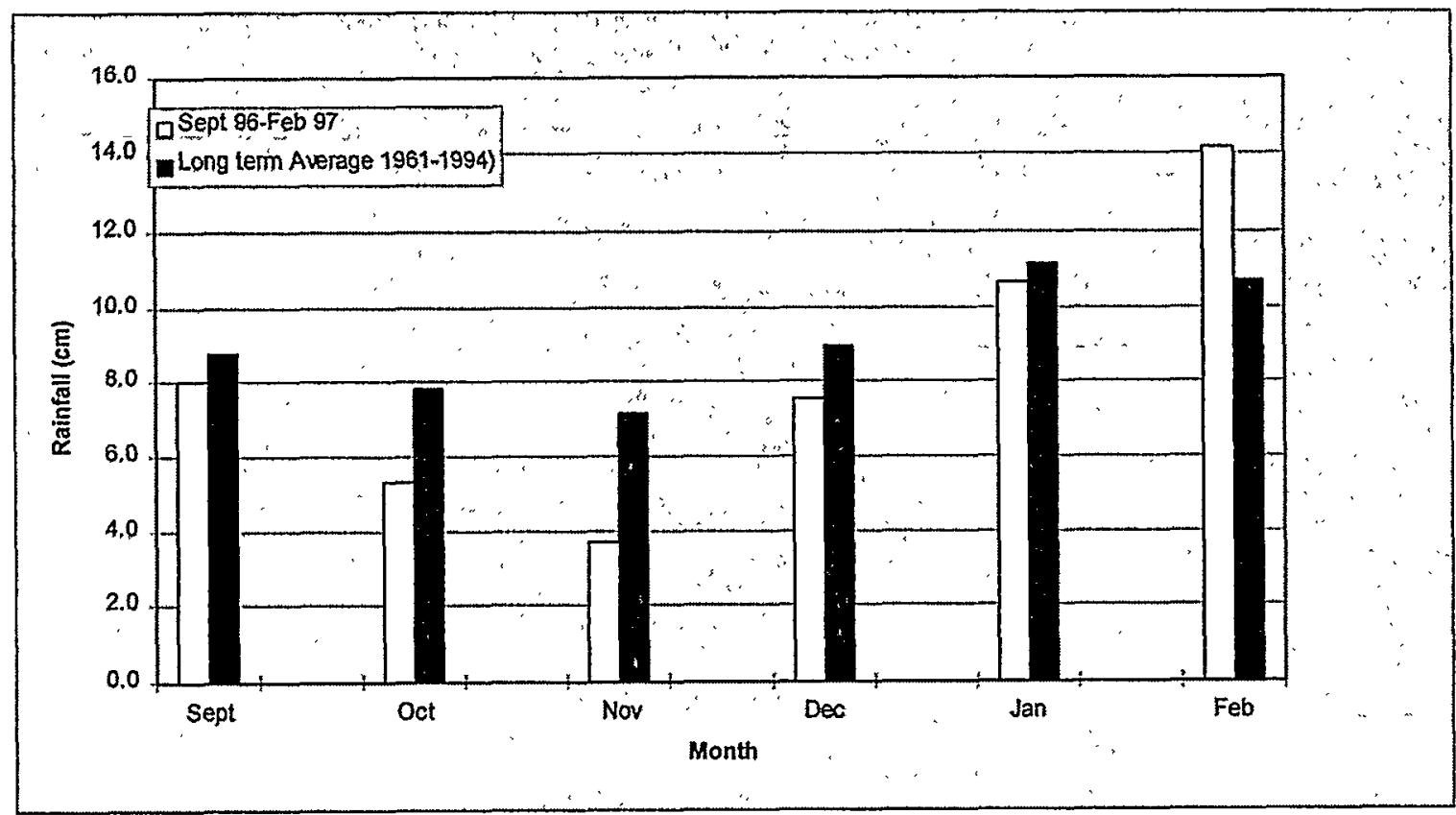

Figure 6. Rainfall, six months prior to sampling and Long term average for F-Area weather station 


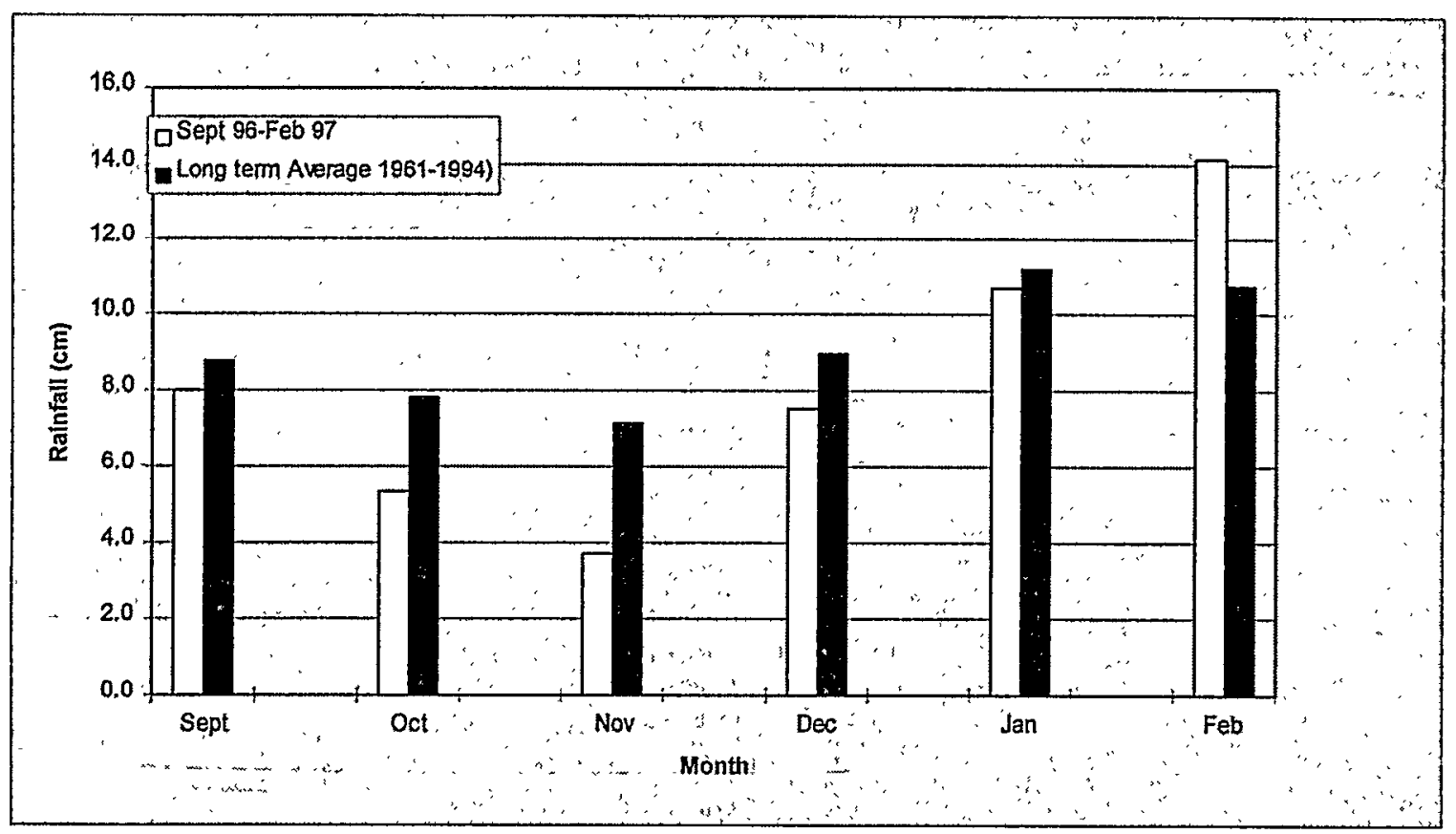

Figure 7. Rainfall six months prior to sampling and Long term average for F-Area weather station

Table 7: Analytes Reported at Concentrations Greater Than Their Method Detection Limit for June 1996

\begin{tabular}{|l|l|}
\hline \multicolumn{2}{|c|}{ Analyte } \\
\hline Aluminum, total recoverable & Nickel, total recoverable \\
\hline Arsenic, total recoverable & Nickel-63 \\
\hline Barium, total recoverable & Nonvolatile beta \\
\hline Cadmium, total recoverable & Radium-226 \\
\hline Calcium, total recoverable & Radium-228 \\
\hline Cesium-137 & Sodium, total recoverable \\
\hline Cobalt, total recoverable & Strontium-90 \\
\hline Cobalt-60 & Technetium-99 \\
\hline Copper, total recoverable & Thallium, total recoverable \\
\hline Gross alpha & Tritium \\
\hline Iodine-129 & Uranium-233/234 \\
\hline Lead, total recoverable & Uranium-238 \\
\hline Lead-212 & Vanadium, total recoverable \\
\hline Magnesium, total recoverable & Zinc, total recoverable \\
\hline Manganese, total recoverable & \\
\hline
\end{tabular}


The conductivity values suggest that some locations are being influenced by elevated concentrations of ions. This is substantiated by the fact that locations exhibiting high conductivity values also exhibit high concentrations of ions, particularly aluminum, calcium, iron, magnesium, and sodium. The $\mathrm{pH}$ values for FMB appear to be near normal. Conductivity values in FMB are somewhat greater than background values as a result of ion contribution (particularly calcium and sodium) from the F- and H-Area Seeplines. The $\mathrm{pH}$ and conductivity trending that has been conducted during the tritium surveys at coinciding sample locations presents a more realistic picture of the $\mathrm{pH}$ and conductivity in these areas, (Koch and Dixon, 1996 and 1997). These surveys show that the $\mathrm{pH}$ has continued to increase to near normal range, (combined average of 5.5). The number of analytes in excess of water quality standards was lower in 1997 than in March of 1989.

The analytes above PDWS or MCL in F and $\mathrm{H}$ Areas were fairly consistent between the two sampling events, however, iron was found in all sample areas (F seepline, $\mathrm{H}$ seepline, FMB, and BG) in excess of its respective water quality standard during the March 1997 sampling event. The analytes found to be in excess of water quality standards from both sampling events more consistently, were aluminum, cadmium, manganese, gross alpha, nonvolatile beta, strontium90 , and tritium.

These analytes exceeded their respective standards in either the $\mathrm{F}$ - or $\mathrm{H}$-area seeplines during both events.
FMB stream samples were above the standards for tritium and manganese during both sampling periods. Aluminum, iron, and strontium-90 were above the standards for one period. Stream samples showed a decrease in the number of analytes exceeding water quality standards compared to those in March of 1989. It is worth noting that when compared to the July 1992 sampling results a significant reduction is seen in number of radionuclides exceeding the standards. A further comparison shows that the number of analytes exceeding the standards has decreased from six to two from 1989 to 1997.

Background samples exceeded the standards in both sampling events for manganese. This suggests that manganese is an element common to the area and not a contaminant. Aluminum and iron were above the standards for one event.

\section{Overall Summary, 1989-1997}

Concentrations of constituents were compared to primary drinking water standards (PDWS), secondary drinking water standards (SDWS), and maximum contaminant levels (MCLs). Statistical comparisons to background concentrations were also performed.

In order to evaluate trending, comparisons were also made with the 1989 results reported by Haselow et al., 1990. Results indicated that most of the nonradiological constituents, particularly sodium and aluminum, had declined at the seeplines and in Fourmile Branch. 
Table 8: Analytes Reported at Concentrations Greater Than Their Method Detection Limit for March 1997

\begin{tabular}{|l|l|}
\hline Analyte & Analyte \\
\hline Aluminum, total recoverable & Manganese, total recoverable \\
\hline Barium, total recoverable & Nickel, total recoverable \\
\hline Cadmium, total recoverable & Nickel-63 \\
\hline Calcium, total recoverable & Nitrate as nitrogen \\
\hline Cesium-137 & Nitrate-nitrite as nitrogen \\
\hline Chloride & Nonvolatile beta \\
\hline Cobalt, total recoverable & Potassium, total recoverable \\
\hline Cobalt-60 & Potassium-40 \\
\hline Copper, total recoverable & Radium-228 \\
\hline Cyanide & Silver, total recoverable \\
\hline Gross alpha & Sodium, total recoverable \\
\hline Hardness as CACO3 & Strontium-90 \\
\hline Iron, total recoverable & Technetium-99 \\
\hline Lead, total recoverable & Tritium \\
\hline Lead-212 & Vanadium, total recoverable \\
\hline Magnesium, total recoverable & Zinc, total recoverable \\
\hline
\end{tabular}

The concentrations of some radionuclides were unchanged from levels reported earlier.

In April 1996, organic and inorganic analyses were discontinued because none of the constituents exceeded primary drinking water standards (PDWS), secondary drinking water standards (SDWS), or maximum contaminant levels (MCLs).

Tables 11-16 in Appendix B and Appendix $\mathrm{C}$ summarize the comparisons that have been made throughout the sampling program (1989-1997). The results in these tables are discussed in the following sections.

\section{Comparisons to Background Concentrations}

Using the combined nonradiological data from all sampling events, Table 11 Appendix B, comparisons of the $\mathrm{F}$-and $\mathrm{H}$ Area seepline locations to background locations from 1992-1997 indicate that alkalinity, aluminum, calcium, copper, magnesium, nitrate/nitrite, and sodium concentrations have been elevated above background levels. Most recently, 19961997, only copper manganese and nitrate/nitrite have had concentrations above background levels.

Using the combined radiological data from all sampling events, Table 14 Appendix C, comparisons to background locations indicate that radium 226, radium 228, gross alpha, iodine-129 cobalt-60, nonvolatile beta and tritium concentrations have been above background levels. Most 
recently, 1996-1997, gross alpha, nonvolatile beta, only cobalt- 60 and tritium concentrations have been above background levels. Radium 226/228 has not been above background concentrations since 1992. Many of these analytes for both seep-lines and FMB show generally decreasing concentrations from 1989 to March 1997.

\section{Comparisons to EPA Standards}

Using the combined nonradiological and radiological data from all sampling events (Table 12 in Appendix B and Table 13 in Appendix C) aluminum, cadmium, iron, manganese, nitrate, americium-249, gross alpha, iodine- 129 , nonvolatile beta, radium 226 , radium 228 , strontium- 89 , strontium 90 tritium uranium-233/234, and uranium 238 have exceeded PDWS, SDWS, or MCL at one or more location, 1989-1997.

More recently, 1996-1997, nitrate/nitrite no longer exceeded these standards. Also, only four radionuclides (gross alpha, nonvolatile beta, strontium-90 and tritium) have been above these standards. This compares with 10 radionuclides that exceeded the standards during the initial sampling event in 1989.

\section{Comparison to 1989 Concentrations}

Tables 13 and 16 in Appendices B and C summarize the comparisons of all sampling events to the initial sampling event conducted in 1989. Since 1992 the number of analytes exceeding 1989 concentrations has decreased by 70 percent. Only aluminum, chloride, and cesium-137 concentrations were above the 1989 concentrations in the 1997 sampling event. This occurred at no more than one of the seepline areas, F H or FMB, for each analyte.

\section{Acknowledgment}

The authors of this report would like to thank Jilene Weber of the Statistical Analysis Section for providing the statistical computations and explanations within this report (Appendix D).

The remainder of this section lists the subcontractors and WSRC organizations responsible for conducting specific activities in support of the 1996 and 1997 sampling events.

- The primary analytical laboratory was General Engineering Laboratory, GEL.

- GEL subcontracted the radiological analysis to Environmental Physics, EP.

- Weston Analytical, WA conducted the split sample analyses.

- WA subcontracted the radiological analysis to Thermo Nuclear, TN.

- Seepline water sampling services were obtained via a task order contract with Rust Environment and Infrastructure Inc. Sampling activities occurred during June 1996 and March 1997. Details of these sampling events have been presented by Rust (1996a and 1997) and are summarized throughout this report.

- The support services for the 1996 and 1997 sampling events were coordinated through the Environmental Groundwater Group, EGG, of the Environmental Monitoring Section, EMS. 
- Analytical data validation services were performed by Exploration Resources, ExR, through EMS managed subcontracts.

- Science Applications International Corporation, SAIC, as a subcontractor to ExR performed mobilization.

\section{References}

Dixon, K.L. and V.A. Rogers. 1992a. Results of the First Quarter Tritium Survey of the F- and H-Area Seeplines: May 1992. WSRC-TR-92304, Westinghouse Savannah River Company, Savannah River Technology Center, Aiken, SC

Dixon, K.L. and V.A. Rogers. 1993b. Results of the Second Quarter Tritium Survey of the F- and H-Area Seeplines: September 1992. WSRCTR-93-129, Westinghouse Savannah River Company, Savannah River Technology Center, Aiken, SC.

Dixon, K.L. and V.A. Rogers. 1993c. Results of the Third Quarter Tritium Survey of the F- and H-Area Seeplines: December 1992. WSRCTR-93-284, Westinghouse Savannah River Company, Savannah River Technology Center, Aiken, SC.

Dixon, K.L. and V.A. Rogers. 1993d. Results of the Fourth Quarter Tritium Survey of the F- and H-Area Seeplines: April 1993. WSRC-TR-93526, Westinghouse Savannah River Company, Savannah River Technology Center, Aiken, SC.
Dixon, K.L. and V.A. Rogers. 1993e. Results of the Quarterly Tritium Survey of Fourmile Branch and its Seeplines in the F- and H-Areas of SRS: June 1993. WSRC-TR-93-656, Westinghouse Savannah ${ }^{-}$River Company, Savannah River Technology Center, Aiken, SC.

Dixon, K.L., and V.A. Rogers, and B.B. Looney. 1994. Results of the Quarterly Tritium Survey of Fourmile Branch and its Seeplines in the $\mathrm{F}$ and $\mathrm{H}$ Areas of SRS: September 1993 (U) WSRCTR-94-0286-ESS, Westinghouse Savannah River Company, Savannah River Technology Center, Aiken, SC.

Dixon, K.L. and V.A. Rogers. 1993. Semi-Annual Sampling of Fourmile Branch and its Seeplines in the F and $\mathrm{H}$ Areas of SRS. WSRC-TR-93-289. Westinghouse Savannah River Company, Savannah River Technology Center, Aiken, SC.

Dixon, K.L., J.W. Koch, and V.A. Rogers. 1995. Semi-Annual Sampling of Fourmile Branch and Its Seeplines in the $\mathrm{F}$ and $\mathrm{H}$ Areas of SRS: February 1993, July 1993, April 1994. (U) WSRC-TR-95-0454, Rev. 1, Westinghouse Savannah River Company, Savannah River Technology Center, Aiken, SC.

Dixon, K.L. and C.L. Cummins. 1994. Sampling and Analysis of Water from Upper Three Runs and its Wetlands Near Tank 16 and the Mixed Waste Management Facility. WSRC-TR-940277, Westinghouse Savannah River 
Company, Savannah River Technology Center, Aiken, SC.

EPD (Environmental Protection Department), Environmental Monitoring Section. June 1997a. Data Summary Report for the Assessment of the Fourmile Branch and its F- and $\mathrm{H}$-Area Seeplines, Radionuclides and Appendix IX Metals (U) ESH-EMS960495, Rev 1, Westinghouse Savannah River Company, Savannah River Technology Center, Aiken, SC.

\section{EPD (Environmental Protection} Department), Environmental Monitoring Section. July 1997b. Data Summary Report for the Assessment of the Fourmile Branch and its F- and H-Area Seeplines, Radionuclides and Appendix IX Metals (U) ESH-EMS960656, Rev 0, Westinghouse Savannah River Company, Savannah River Technology Center, Aiken, SC.

Fenimore, J.W. and J.H. Horton. 1972. Rating History and Environmental Effects of Seepage Basins in Chemical Separations Areas of the Savannah River Plant. DPST-72-548, E.I. du Pont de Nemours and Company, Savannah River Laboratory, Aiken, SC.

Haselow, J.S., M. Harris, B.B. Looney, N.V. Halverson, and J.B. Gladden. 1990. Analysis of Soil and Water at the Fourmile Branch Seepline Near the F- and H-Area of SRS. WSRC-RP-900591, Westinghouse Savannah River Company, Savannah River Laboratory, Aiken, SC.
Killian, T.H., N.L. Kolb, P. Corbo, and I.W. Marine. 1985a. F-Area Seepage Basins. DPST-85-704, E.I. du Pont de Nemours and Company, Savannah River Laboratory, Aiken, SC.

Killian, T.H., N.L. Kolb, P. Corbo, and I.W. Marine. 1985b. H-Area Seepage Basins. DPST-85-706, E.I. du Pont de Nemours and Company, Savannah River Laboratory, Aiken, SC.

Koch, J.W. and K.L. Dixon. 1994. Results of the Quarterly Tritium Survey of Fourmile Branch and its Seeplines in the $\mathrm{F}$ and $\mathrm{H}$ Areas of SRS: December 1994. (U) WSRC-TR-95-0300, Westinghouse Savannah River Company, Savannah River Technology Center, Aiken, SC.

Koch, J.W. and K.L. Dixon. 1995. Results of the Quarterly Tritium Survey of Fourmile Branch and its Seeplines in the F and H Areas of SRS: May 1995. (U) WSRC-TR-95-0369, Westinghouse Savannah River Company, Savannah River Technology Center, Aiken, SC.

Koch, J.W. and K.L. Dixon. 1996. Results of the Quarterly Tritium Survey of Fourmile Branch and its Seeplines in the $\mathrm{F}$ and $\mathrm{H}$ Areas of SRS: March 1996. (U) WSRC-TR-96-0215, Westinghouse Savannah River Company, Savannah River Technology Center, Aiken, SC. 
Koch, J.W. and K.L. Dixon. 1997. Results of the Quarterly Tritium Survey of Fourmile Branch and its Seeplines in the $\mathrm{F}$ and $\mathrm{H}$ Areas of SRS: September 1996 and 1989-1996 Trending. (U) WSRC-TR-97-0109, Westinghouse Savannah River Company, Savannah River Technology Center, Aiken, SC.

Koch, J.W. and K.L. Dixon. 1997. Tritium Concentrations in the F- and H-Area Seeplines and Fourmile Branch at SRS: March 1997 and 1989-1997 Trending. (U) WSRC-TR-97-00359, Westinghouse Savannah River Company, Savannah River Technology Center, Aiken, SC.

Leblanc, D. and C. Loehle. 1990. The Effect of Contaminated Groundwater on Tree Growth: A Tree Ring Analysis (U). WSRC-RP-90-552. Savannah River Laboratory, Westinghouse Savannah River Company, Aiken, SC.

Levene, H. 1960. Robust Tests for the Equality of Variances. In I. Olkin (ed), Contributions to Probability and Statistics. Stanford University Press.

Lilliefors, H.W. 1967. On the Kolmogorov-Smirnov Test for Normality with Mean and Variance Unknown. Journal of American Statistical Association, Vol. 64, pp. 399-401.

Loehle, C. 1990. Recovery of Contaminated Wetland Soils at SRS by Natural Rainfall: An Experimental Toxicological Study. WSRC-RD-9014. Savannah River Laboratory,
Westinghouse Savannah River Company, Aiken, SC.

Looney, B.B., J.E. Cantrell, and J.R. Cook. 1988. Sampling and Analysis of Surface Water in the Vicinity of the Fand H-Area Seepage Basins. DPST88-229, E.I. du Pont de Nemours and Company, Savannah River Laboratory, Aiken, SC.

Looney, B.B., J.S. Haselow, C.M. Lewis, M.K. Harris, D.E. Wyatt, and C.S. Hetrick. 1993. Projected Tritium Releases from F and H Aréa Seepage Basins and the Solid Waste Disposal Facilities to Fourmile Branch (U). WSRC-RP-93-459, Westinghouse Savannah River Company, Savannah River Technology Center, Aiken, SC.

Metcalf and Eddy. 1993a. Four Mile Creek Semi-Annual Sampling Report: July 1993 Sampling Event. Aiken, SC.

Metcalf and Eddy. 1993b. Four Mile Creek Semi-Annual Sampling Report: January 1993 Sampling Event. Aiken, $\mathrm{SC}$

Metcalf and Eddy. 1994. Fourmile Branch Semi-Annual Sampling Report: April 1994 Sampling Event. Aiken, SC

Miller, R.G., Jr. 1981. Simultaneous Statistical Inference. Second Edition. Springer-Verlag, New York, NY. 
Nelson, E.A. and Erwin, J.E. 1994. Current Vegetation Characteristics Within Tree-Kill Zones of F- and $\mathrm{H}$ Areas (U): April 1994. WSRC-TR-940203, Westinghouse Savannah River Company, Savannah River Technology Center, Aiken, SC.

Steel, R.G.D. and J.H. Torrie. 1980. Principles and Procedures of Statistics, A Biometric Approach. Second Edition. McGraw-Hill Book Company, New York, NY.

U.S. Department of Energy. (DOE) 1992. Environmental Measurements Laboratory of the U.S. DOE, 376 Hudson St., New York, NY.

U.S. Environmental Protection Agency (EPA). 1977. National Interim Primary Drinking Water Regulations. EPA570/9-76-003, Washington, D.C.

U.S. Environmental Protection Agency (EPA). 1980. Prescribed Procedures for Measurement of Radioactivity in Drinking Water. EPA-600/4-80-32. Cincinnati, $\mathrm{OH}$.

U.S. Environmental Protection Agency (EPA). 1983. Methods for Chemical Analysis of Water and Wastes. PB84128677. Cincinnati, $\mathrm{OH}$.

U.S. Environmental Protection Agency (EPA). 1986a. Test Methods for Evaluating Solid Waste, Vol. 1A, 1B, and 1C, Third edition. SW846. Washington, D.C.

U.S. Environmental Protection Agency (EPA). 1986b. Water Pollution
Control; National Primary Drinking Water Regulations; Radionuclides; Proposed. Federal Register, September 30, 1986, pp. 34835-34862, Washington, D.C.

U.S. Environmental Protection Agency (EPA). 1991. National Primary Drinking Water Regulations; Radionuclides; Proposed; Federal Register, July 18, 1991, pp. 3305233127, Washington, D.C.

U.S. Environmental Protection Agency (EPA). 1994. Drinking Water Regulations and Health Advisories. EPA 822-R-94-001, Washington, D.C. 


\section{Appendix A}

Water Analytical Methods and Detection Limits for General Engineering/Environmental Physics and Weston Analytical/Thermo Nuclear 
Table 9a. Water Analytical Methods and Detection Limits for General Engineering/Environmental Physics (Radionuclide Indicators and Gamma PHA)

\begin{tabular}{|c|c|c|c|c|}
\hline Analyte & Method & Unit & EQL & Reference \\
\hline Actinium-228 & EPIA-013 & $\mathrm{pCi} / \mathrm{L}$ & $\overline{\mathrm{NA}^{1}}$ & $\overline{G E}$ \\
\hline Americium-241 & EPIA-011 & $\mathrm{pCi} / \mathrm{L}$ & NA & GE \\
\hline Antimony-124 & EPIA-013 & $\mathrm{pCi} / \mathrm{L}$ & NA & GE \\
\hline Antimony-125 & EPIA-013 & $\mathrm{pCi} / \mathrm{L}$ & NA & GE \\
\hline Barium-133 & EPIA-013 & $\mathrm{pCi} / \mathrm{L}$ & $\mathrm{NA}$ & GE \\
\hline Cerium-144 & EPIA-013 & $\mathrm{pCi} / \mathrm{L}$ & $\overline{\mathrm{NA}}$ & GE \\
\hline Cesium-134 & EPIA-013 & $\mathrm{pCi} / \mathrm{L}$ & NA & GE \\
\hline Cesium-137 & EPIA-013 & $\overline{\mathrm{pCi} / \mathrm{L}}$ & $\overline{\mathrm{NA}}$ & $G$ \\
\hline Cobalt- 57 & EPIA-013 & $\mathrm{pCi} / \mathrm{L}$ & $\overline{\mathrm{NA}}$ & $\overline{G E}$ \\
\hline Cobalt-58 & EPIA-013 & $\overline{\mathrm{pCi} / \mathrm{L}}$ & $\overline{\mathrm{NA}}$ & $G$ \\
\hline Cobalt- 60 & EPIA-013 & $\mathrm{pCi} / \mathrm{L}$ & $\overline{N A}$ & $\overline{G E}$ \\
\hline Curium-242 & EPIA-011 & $\mathrm{pCi} / \mathrm{L}$ & NA & $\mathrm{GE}$ \\
\hline Curium-243/244 & EPIA-011 & $\mathrm{pCi} / \mathrm{L}$ & NA & $\mathrm{GE}$ \\
\hline Curium-245/246 & EPIA-011 & $\mathrm{pCi} / \mathrm{L}$ & NA & GE \\
\hline Europium-152 & EPIA-013 & $\mathrm{pCi} / \mathrm{L}$ & NA & GE \\
\hline Europium-154 & EPIA-013 & $\mathrm{pCi} / \mathrm{L}$ & NA & GE \\
\hline Europium-155 & EPIA-013 & $\mathrm{pCi} / \mathrm{L}$ & NA & $\overline{G E}$ \\
\hline Gamma PHA ${ }^{2}$ & EPIA-013 & $\mathrm{pCi} / \mathrm{L}$ & NA & GE \\
\hline Gross alpha & EPIA-001 & $\mathrm{pCi} / \mathrm{L}$ & $\mathrm{NA}$ & $\overline{G E}$ \\
\hline Iodine-129 & EPIA-006 & $\mathrm{pCi} / \mathrm{L}$ & $\mathrm{NA}$ & GE \\
\hline Lead-212 & EPIA-013 & $\mathrm{pCi} / \mathrm{L}$ & NA & $\mathrm{GE}$ \\
\hline Manganese-54 & EPIA-013 & $\mathrm{pCi} / \mathrm{L}$ & NA & GE \\
\hline Neptunium-237 & EPIA-012 & $\mathrm{pCi} / \mathrm{L}$ & $\overline{\mathrm{NA}}$ & $\mathrm{GE}$ \\
\hline Neptunium-239 & EPIA-013 & $\mathrm{pCi} / \mathrm{L}$ & NA & GE \\
\hline Nickel-63 & EPIA-022 & $\mathrm{pCi} / \mathrm{L}$ & NA & GE \\
\hline Nonvolatile beta & EPIA-001 & $\mathrm{pCi} / \mathrm{L}$ & NA & $\overline{\mathrm{GE}}$ \\
\hline Potassium-40 & EPIA-013 & $\mathrm{pCi} / \mathrm{L}$ & $\mathrm{NA}$ & GE \\
\hline Promethium-144 & EPIA-013 & $\mathrm{pCi} / \mathrm{L}$ & NA & $\mathrm{GE}$ \\
\hline
\end{tabular}

I $\mathrm{NA}=$ Not available. The laboratory calculates the MDA for radionuclides at the time of analysis.

2 Radionuclides reported by this method vary. Typically, cesium-134, cesium-137, cobalt-60, iodine-129, and potassium-40 may be reported if positive. 
WSRC-TR-98-00287

(Table 9a. continued)

\begin{tabular}{|l|l|l|l|l|}
\hline Analyte & Method & Unit & EQL & Reference \\
\hline Promethium-146 & EPIA-013 & $\mathrm{pCi} / \mathrm{L}$ & $\mathrm{NA}$ & $\mathrm{GE}$ \\
\hline Radium-226 & EPIA-008 & $\mathrm{pCi} / \mathrm{L}$ & $\mathrm{NA}$ & $\mathrm{GE}$ \\
\hline Radium-228 & EPIA-009 & $\mathrm{pCi} / \mathrm{L}$ & $\mathrm{NA}$ & $\mathrm{GE}$ \\
\hline Ruthenium-106 & EPIA-013 & $\mathrm{pCi} / \mathrm{L}$ & $\mathrm{NA}$ & $\mathrm{GE}$ \\
\hline Sodium-22 & EPIA-013 & $\mathrm{pCi} / \mathrm{L}$ & $\mathrm{NA}$ & $\mathrm{GE}$ \\
\hline Strontium-90 & EPIA-004 & $\mathrm{pCi} / \mathrm{L}$ & $\mathrm{NA}$ & $\mathrm{GE}$ \\
\hline Technetium-99 & EPIA-005 & $\mathrm{pCi} / \mathrm{L}$ & $\mathrm{NA}$ & $\mathrm{GE}$ \\
\hline Tin-113 & EPIA-013 & $\mathrm{pCi} / \mathrm{L}$ & $\mathrm{NA}$ & $\mathrm{GE}$ \\
\hline Yttrium-88 & EPIA-013 & $\mathrm{pCi} / \mathrm{L}$ & $\mathrm{NA}$ & $\mathrm{GE}$ \\
\hline Zinc-65 & EPIA-013 & $\mathrm{pCi} / \mathrm{L}$ & $\mathrm{NA}$ & $\mathrm{GE}$ \\
\hline Zirconium-95 & EPIA-013 & $\mathrm{pCi/L}$ & $\mathrm{NA}$ & $\mathrm{GE}$ \\
\hline
\end{tabular}

Table 9b. Water Analytical Methods and Detection Limits for General Engineering Laboratories, Inc. (Appendix IX Metals and Cyanide)

\begin{tabular}{|l|l|l|l|l|}
\hline Analyte & Method & Unit & EQL & Reference \\
\hline Antimony & EPA6010A & $\mathrm{mg} / \mathrm{kg}$ & 5.0 & USEPA, 1986 \\
\hline Arsenic & EPA6010A & $\mu \mathrm{g} / \mathrm{L}$ & 5.0 & USEPA, 1986 \\
\hline Barium & EPA6010A & $\mu \mathrm{g} / \mathrm{L}$ & 3.0 & USEPA, 1986 \\
\hline Beryllium & EPA6010A & $\mu \mathrm{g} / \mathrm{L}$ & 3.0 & USEPA, 1986 \\
\hline Cadmium & EPA6010A & $\mu \mathrm{g} / \mathrm{L}$ & 2.0 & USEPA, 1986 \\
\hline Chromium & EPA6010A & $\mu \mathrm{g} / \mathrm{L}$ & 4.0 & USEPA, 1986 \\
\hline Cobalt & EPA6010A & $\mu \mathrm{g} / \mathrm{L}$ & 4.0 & USEPA, 1986 \\
\hline Copper & EPA6010A & $\mu \mathrm{g} / \mathrm{L}$ & 4.0 & USEPA, 1986 \\
\hline Cyanide & EPA335.3 & $\mu \mathrm{g} / \mathrm{L}$ & 10.0 & USEPA, 1983 \\
\hline Lead & EPA6010A & $\mu \mathrm{g} / \mathrm{L}$ & 5.0 & USEPA, 1986 \\
\hline Mercury & EPA7470 & $\mu \mathrm{g} / \mathrm{L}$ & 0.2 & USEPA, 1986 \\
\hline Nickel & EPA6010A & $\mu \mathrm{g} / \mathrm{L}$ & 10.0 & USEPA, 1986 \\
\hline Selenium & EPA6010A & $\mu \mathrm{g} / \mathrm{L}$ & 5.0 & USEPA, 1986 \\
\hline Silver & EPA6010A & $\mu \mathrm{g} / \mathrm{L}$ & 2.0 & USEPA, 1986 \\
\hline Thallium & EPA6010A & $\mu \mathrm{g} / \mathrm{L}$ & 5.0 & USEPA, 1986 \\
\hline Tin & EPA6010A & $\mu \mathrm{g} / \mathrm{L}$ & 50.0 & USEPA, 1986 \\
\hline Vanadium & EPA6010A & $\mu \mathrm{g} / \mathrm{L}$ & 10.0 & USEPA, 1986 \\
\hline Zinc & EPA6010A & $\mu \mathrm{g} / \mathrm{L}$ & 5.0 & USEPA, 1986 \\
\hline
\end{tabular}


Table 10a. Water Analytical Methods and Detection Limits for Roy F. Weston/Thermo Nuclear (TNU) (Radionuclide Indicators and Gamma PHA)

\begin{tabular}{|c|c|c|c|c|}
\hline Analyte & Method & Unit & EQL & Reference \\
\hline Actinium-228 & EPA901.0MOD & $\mathrm{pCi} / \mathrm{L}$ & $\mathrm{NA}^{3}$ & TNU \\
\hline Antimony-124 & EPA901.0MOD & $\mathrm{pCi} / \mathrm{L}$ & $\overline{\mathrm{NA}}$ & TNU \\
\hline Antimony-125 & EPA901.0MOD & $\mathrm{pCi} / \mathrm{L}$ & $\mathrm{NA}$ & TNU \\
\hline Barium-133 & EPA901.0MOD & $\mathrm{pCi} / \mathrm{L}$ & $\mathrm{NA}$ & TNU \\
\hline Cerium-144 & EPA901.0MOD & $\mathrm{pCi} / \mathrm{L}$ & $\mathrm{NA}$ & TNU \\
\hline Cesium-134 & EPA901.0MOD & $\mathrm{pCi} / \mathrm{L}$ & $\mathrm{NA}$ & TNU \\
\hline Cesium-137 & EPA901.0MOD & $\mathrm{pCi} / \mathrm{L}$ & $\mathrm{NA}$ & TNU \\
\hline Cobalt-57 & EPA901.0MOD & $\mathrm{pCi} / \mathrm{L}$ & $\mathrm{NA}$ & TNU \\
\hline Cobalt-58 & EPA901.0MOD & $\mathrm{pCi} / \mathrm{L}$ & NA & TNU \\
\hline Cobalt-60 & EPA901.0MOD & $\mathrm{pCi} / \mathrm{L}$ & NA & TNU \\
\hline Europium-152 & EPA901.0MOD & $\mathrm{pCi} / \mathrm{L}$ & NA & TNU \\
\hline Europium-154 & EPA901.0MOD & $\mathrm{pCi} / \mathrm{L}$ & NA & TNU \\
\hline Europium-155 & EPA901.0MOD & $\mathrm{pCi} / \mathrm{L}$ & NA & TNU \\
\hline Gamma PHA $^{4}$ & EPA901.0MOD & $\mathrm{pCi} / \mathrm{L}$ & NA & TNU \\
\hline Gross alpha & EPA900.0 & $\mathrm{pCi} / \mathrm{L}$ & NA & Krieger, 1980 \\
\hline Iodine-129 & EPA901.1MOD & $\mathrm{pCi} / \mathrm{L}$ & NA & TNU \\
\hline Lead-212 & EPA901.0MOD & $\mathrm{pCi} / \mathrm{L}$ & NA & TNU \\
\hline Manganese-54 & EPA901.0MOD & $\mathrm{pCi} / \mathrm{L}$ & NA & TNU \\
\hline Neptunium-237 & EPA901.0MOD & $\mathrm{pCi} / \mathrm{L}$ & $\mathrm{NA}$ & TNU \\
\hline Neptunium-239 & EPA901.0MOD & $\mathrm{pCi} / \mathrm{L}$ & $\mathrm{NA}$ & TNU \\
\hline Nickel-63 & SM3500NIEMOD & $\mathrm{pCi} / \mathrm{L}$ & $\mathrm{NA}$ & TNU \\
\hline Nonvolatile beta & EPA900.0 & $\mathrm{pCi} / \mathrm{L}$ & $\mathrm{NA}$ & Krieger, 1980 \\
\hline Potassium-40 & EPA901.0MOD & $\mathrm{pCi} / \mathrm{L}$ & NA & TNU \\
\hline Promethium-144 & EPA901.0MOD & $\mathrm{pCi} / \mathrm{L}$ & $\mathrm{NA}$ & TNU \\
\hline Promethium-146 & EPA901.0MOD & $\mathrm{pCi} / \mathrm{L}$ & $\mathrm{NA}$ & TNU \\
\hline Radium-228 & EPA904.0MOD & $\mathrm{pCi} / \mathrm{L}$ & $\mathrm{NA}$ & TNU \\
\hline Ruthenium-106 & EPA901.0MOD & $\mathrm{pCi} / \mathrm{L}$ & NA & TNU \\
\hline Sodium-22 & EPA901.0MOD & $\mathrm{pCi} / \mathrm{L}$ & $\mathrm{NA}$ & TNU \\
\hline Strontium-90 & EMLSR02MOD & $\mathrm{pCi} / \mathrm{L}$ & NA & TNU \\
\hline
\end{tabular}

${ }^{3} \mathrm{NA}=$ Not available. The laboratory calculates the $\mathrm{MDA}$ for radiochemicals at the time of analysis. 


\begin{tabular}{|l|l|l|l|l|}
\hline Analyte & Method & Unit & EQL & Reference \\
\hline Technetium-99 & EICHROMTC1MOD & $\mathrm{pCi} / \mathrm{L}$ & $\mathrm{NA}$ & TNU \\
\hline Tin-113 & EPA901.0MOD & $\mathrm{pCi} / \mathrm{L}$ & $\mathrm{NA}$ & TNU \\
\hline Yttrium-88 & EPA901.0MOD & $\mathrm{pCi} / \mathrm{L}$ & $\mathrm{NA}$ & TNU \\
\hline Zinc-65 & EPA901.0MOD & $\mathrm{pCi} / \mathrm{L}$ & $\mathrm{NA}$ & TNU \\
\hline Zirconium-95 & EPA901.0MOD & $\mathrm{pCi} / \mathrm{L}$ & $\mathrm{NA}$ & TNU \\
\hline \\
Radionuclides reported by this method vary. Typically, cesium-134, cesium-137, cobalt-60, \\
iodine-129, and potassium-40 may be reported if positive. \\
\hline
\end{tabular}

Table 10b. Water Analytical Methods and Detection Limits for Roy F. Weston, Appendix IX Metals (total recoverable) and Cyanide

\begin{tabular}{|l|l|l|l|l|}
\hline Analyte & Method & Unit & EQL & Reference \\
\hline Antimony & EPA6010 & $\mu \mathrm{g} / \mathrm{L}$ & 27.0 & EPA, 1986 \\
\hline Arsenic & EPA6010 & $\mu \mathrm{g} / \mathrm{L}$ & 40.0 & EPA, 1986 \\
\hline Barium & EPA6010 & $\mu \mathrm{g} / \mathrm{L}$ & 1.8 & EPA, 1986 \\
\hline Beryllium & EPA6010 & $\mu \mathrm{g} / \mathrm{L}$ & 1.6 & EPA, 1986 \\
\hline Cadmium & EPA6010 & $\mu \mathrm{g} / \mathrm{L}$ & 4.7 & EPA, 1986 \\
\hline Chromium & EPA6010 & $\mu \mathrm{g} / \mathrm{L}$ & 7.0 & EPA, 1986 \\
\hline Cobalt & EPA6010 & $\mu \mathrm{g} / \mathrm{L}$ & 4.5 & EPA, 1986 \\
\hline Copper & EPA6010 & $\mu \mathrm{g} / \mathrm{L}$ & 15.0 & EPA, 1986 \\
\hline Cyanide & EPA9010A & $\mu \mathrm{g} / \mathrm{L}$ & 15.2 & EPA, 1986 \\
\hline Lead & EPA6010 & $\mu \mathrm{g} / \mathrm{L}$ & 47.0 & EPA, 1986 \\
\hline Mercury & EPA7470 & $\mu \mathrm{g} / \mathrm{L}$ & 0.7 & EPA, 1986 \\
\hline Nickel & EPA6010 & $\mu \mathrm{g} / \mathrm{L}$ & 26.0 & EPA, 1986 \\
\hline Selenium & EPA6010 & $\mu \mathrm{g} / \mathrm{L}$ & 66.0 & EPA, 1986 \\
\hline Silver & EPA6010 & $\mu \mathrm{g} / \mathrm{L}$ & 5.0 & EPA, 1986 \\
\hline Thallium & EPA6010 & $\mu \mathrm{g} / \mathrm{L}$ & 55.0 & EPA, 1986 \\
\hline Tin & EPA6010 & $\mu \mathrm{g} / \mathrm{L}$ & 70.0 & EPA, 1986 \\
\hline Vanadium & EPA6010 & $\mu \mathrm{g} / \mathrm{L}$ & 6.9 & EPA, 1986 \\
\hline Zinc & EPA6010 & $\mu \mathrm{g} / \mathrm{L}$ & 53.0 & EPA, 1986 \\
\hline
\end{tabular}




\section{Appendix B}

F- and H-Area Seeplines and FMB Comparisons Against Region IV Standards, Background Concentrations, and 1989 Concentrations for Non-Radionuclides 
Table 11. Constituents in surface water whose $95 \%$ UCI exceeded background measurements at one or more location along the F- and H-Area seeplines and FMB, 1992-1997.

\begin{tabular}{|c|c|c|c|c|c|c|c|c|c|c|c|c|c|c|c|c|c|c|}
\hline Sample Date & \multicolumn{3}{|c|}{1992} & \multicolumn{3}{|c|}{ Feb 1993} & \multicolumn{3}{|c|}{ July 1993} & \multicolumn{3}{|c|}{1994} & \multicolumn{3}{|c|}{1996} & \multicolumn{3}{|c|}{1997} \\
\hline Constituent & $\bar{F}$ & $\bar{H}$ & $\begin{array}{l}\mathbf{F} \\
\mathbf{M} \\
\mathbf{B} \\
\end{array}$ & $\mathbf{F}$ & $\bar{H}$ & $\begin{array}{l}\mathbf{F} \\
\mathbf{M} \\
\mathbf{B} \\
\end{array}$ & F & $\mathbf{H}$ & $\begin{array}{l}\mathbf{F} \\
\mathbf{M} \\
\mathbf{B}\end{array}$ & $\bar{F}$ & $\mathbf{H}$ & $\begin{array}{l}\mathbf{F} \\
\mathbf{M} \\
\mathbf{B}\end{array}$ & $\overline{\mathbf{F}}$ & $\mathbf{H}$ & $\begin{array}{l}\mathbf{F} \\
\mathbf{M} \\
\mathbf{B}\end{array}$ & $\bar{F}$ & $\mathbf{H}^{\prime}$ & $\begin{array}{l}\mathbf{F} \\
\mathbf{M} \\
\mathbf{B}\end{array}$ \\
\hline Alkalinity & $\mathrm{X}$ & $\bar{X}$ & & & & & $\therefore$ & & & & & & & & & & & \\
\hline Aluminum & & $\mathrm{X}$ & & $\mathbf{N}$ & $\mathbf{N}$ & $\mathbf{N}$ & $\mathbf{N}$ & $\mathbf{N}$ & $\mathbf{N}$ & & & $\mathbf{N}$ & & $\mathbf{N}$ & $\mathbf{N}$ & & & $\mathbf{N}$ \\
\hline Ammonia as $\mathrm{N}$ & $\because$ & & 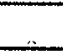 & $\mathbf{O}$ & $\mathbf{O}$ & $\mathbf{O}$ & 0 & $\mathbf{0}$ & .0 & & & $\mathbf{0}$ & & 0 & 0 & & & $\mathbf{O}$ \\
\hline Antimony & $\therefore$ & & 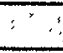 & $\mathbf{N}$ & $\mathbf{N}$ & $\mathbf{N}$ & $N$ & $\mathbf{N}$ & $\mathbf{N}$ & & & $\mathbf{N}$ & & $\mathbf{N}$ & $\mathbf{N}$ & & & $\mathbf{N}$ \\
\hline Arsenic & & & $\because$ & $\mathbf{E}$ & $\mathbf{E}$ & $\mathbf{E}$ & $\mathbf{E}$ & $\mathbf{E}$ & $\mathbf{E}$ & & & $\mathbf{E}$ & & $\mathbf{E}$ & $\mathbf{E}$ & & & $\mathbf{E}$ \\
\hline Barium & & & & & & & & & & & & & & & & & & \\
\hline Beryllium & & & & & & & & & $\%$ & & & & & & & & & \\
\hline Cadmium & & & & & & & $\because{ }^{\prime \prime}$ & $\because=$ & . & & & & & & & & & \\
\hline Calcium & $\bar{X}$ & $\bar{X}$ & & & & & & & $\therefore$ & $\mathbf{X}$ & & & & $"$ & & & & \\
\hline Chloride & & & & & & & $\cdots$ & दो & & & & & & & '. & & & \\
\hline Chromium & & & & & & & & & & & & & & & & & & \\
\hline Cobalt & & & & & & & ' & & & & & & & & 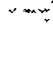 & & & \\
\hline Copper & & & & & & & ; & & & & & & & & & & $\mathbf{X}$ & \\
\hline Cyanide & & & & & & & & & . & & & & & & 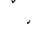 & & & \\
\hline Hardness & & & & & & & & & & & & & & & & & & \\
\hline Iron & & & & & & & & & & & & & & & & & & \\
\hline Lead & & & 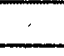 & & & & & & & & & & & & & & & \\
\hline Magnesium & & & & & & & & & & & & & $\mathrm{X}$ & & . & $\mathbf{X}$ & $\mathbf{X}$ & \\
\hline Manganese & $\mathbf{X}$ & & & & & & & & & & & & & & & & & \\
\hline Mercury & & & & & & & & & & & & & & & & & & \\
\hline Nickel & . & & 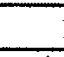 & $\mathbf{N}$ & $\mathbf{N}$ & $\mathbf{N}$ & $\mathbf{N}$ & $\mathbf{N}$ & $\mathbf{N}$ & & & $\mathbf{N}$ & & $\mathbf{N}$ & $\mathbf{N}$ & & & $\mathbf{N}$ \\
\hline Nitrate & & & & $\mathbf{0}$ & $\mathbf{O}$ & $\mathbf{0}$ & 0 & 0 & $\mathbf{0}$ & & & O & & $\mathbf{0}$ & 0 & & & $\mathbf{O}$ \\
\hline Nitrate/Nitrite & & & & $\mathbf{N}$ & $\mathbf{N}$ & $\mathbf{N}$ & $\mathbf{N}$ & $\mathbf{N}$ & N & & & $\mathbf{N}$ & & $\mathbf{N}$ & $\mathbf{N}$ & & & $\mathbf{N}$ \\
\hline Potassium & & & & $\mathbf{E}$ & $\mathbf{E}$ & $\mathbf{E}$ & $\mathbf{E}$ & $\mathbf{E}$ : & $\mathbf{E}$ & & & $\mathbf{E}$ & & $\mathbf{E}$ & $\mathbf{E}$ & & & $\mathbf{E}$ \\
\hline Selenium & . & & $\because$ & & & & $\cdots$, & & $\therefore$ & & & & & & & & & \\
\hline Silver & & & $n$ & & & & $\because \cdots$ & & $\because \because$ & & & & & & & & & \\
\hline Sodium & & $\bar{X}$ & & & & & 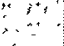 & & 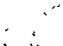 & & $\mathbf{X}$ & & & & & & & \\
\hline Thallium & $\therefore$ & - & & & & & $\therefore$ & $\cdots$ & 3 & & & & & & $\therefore$ & & & \\
\hline Tin & & $\therefore$ & & & & & $m=$ & $\because \because$ & & & & & & & & & & \\
\hline Vanadium & $\therefore$ & & & & & & 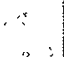 & & $\therefore$ & & & & & & & & & \\
\hline Zinc & & & & & & & & & & & & & & & & & & \\
\hline
\end{tabular}


Table 12. Constituents in surface water whose $95 \%$ UCl exceeded PDWS, SDWS, or MCL at one or more location along the F- and H-Area seeplines and FMB, 1989-1997.

\begin{tabular}{|c|c|c|c|c|c|c|c|c|c|c|c|c|c|c|c|c|c|c|c|c|c|}
\hline Sample Date & \multicolumn{3}{|c|}{1989} & \multicolumn{3}{|c|}{1992} & \multicolumn{3}{|c|}{ Feb 1993} & \multicolumn{3}{|c|}{ July 1993} & \multicolumn{3}{|c|}{1994} & \multicolumn{3}{|c|}{1996} & \multicolumn{3}{|c|}{1997} \\
\hline Constituent & $\overline{F "}$ & $\overline{\mathbf{H}}$ & $\begin{array}{l}\mathbf{F} \\
\mathbf{M} \\
\mathbf{B}\end{array}$ & $\bar{F}$ & $\mathbf{H}$ & $\begin{array}{c}\mathbf{F} \\
\mathbf{M} \\
\mathbf{B}\end{array}$ & $\mathbf{F}$ & {$\left[\begin{array}{l}\mathbf{H} \\
\cdots \\
\cdots\end{array}\right.$} & $\begin{array}{l}\overline{\mathbf{F}} \\
\mathbf{M} \\
\mathbf{B}\end{array}$ & $\begin{array}{l}\mathbf{F}_{1} \\
\vdots\end{array}$ & H & $\begin{array}{l}\mathbf{F} \\
\mathbf{M} \\
\mathbf{B}\end{array}$ & $\bar{F}$ & $\begin{array}{l}\mathbf{H} \\
\\
\vdots\end{array}$ & $\begin{array}{l}\mathbf{F} \\
\mathbf{M} \\
\mathbf{B}\end{array}$ & $\mathbf{F}$ & $\mathrm{H}$ & $\begin{array}{c}\mathbf{F} \\
\mathbf{M} \\
\mathbf{B}\end{array}$ & $\cdots$ & $\mathbf{H}$ & $\begin{array}{l}\mathbf{F} \\
\mathbf{M} \\
\mathbf{B}\end{array}$ \\
\hline Aluminum & & & & & & & & . & 5 & & & & $\because$ & $\because$ & & $\bar{x}$ & $\bar{X}$ & $\bar{X}$ & $\bar{x}$ & $\bar{X}$ & , \\
\hline Ammonia as $\mathrm{N}$ & & & $\mathbf{N}$ & & & $\mathbf{N}$ & & & & & & & $\therefore$ & $\therefore$ & $\mathbf{N}$ & & & & & & \\
\hline Antimony & & & 0 & & & $\mathbf{O}$ & & & 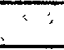 & & & & - & & $\mathbf{O}$ & & & & $\therefore$ & & \\
\hline Arsenic & & & $\mathbf{N}$ & & & $\mathbf{N}$ & & $\cdots$ & . & & & $\cdot$ & $\therefore$ & & $\mathbf{N}$ & & & & & & \\
\hline Barium & & & $\mathbf{E}^{\prime \prime}$ & & & $\mathbf{E}$ & $\therefore$ & & $\vdots$ & & & & $\therefore$ & & $\mathbf{E}$ & & & & $\ldots$ & & \\
\hline Beryllium & & & & & & & & $\therefore$ & & & & & & & & & & & & & \\
\hline Cadmium & $\mathbf{X}$ & & & & & & $\bar{X}$ & $\bar{X}$ & $\overline{\mathbf{X}}$ & $\mathbf{X}$ & $\mathbf{X}$ & $\mathbf{X}$ & & & & $\mathbf{X}$ & & & $\mathbf{X}$ & & . \\
\hline Chloride & & & & & & & & & & & & & & & & & & & & & 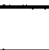 \\
\hline Chromium & & & & & & & & & & & & & & & & & & & & - & 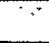 \\
\hline Cobalt & & & & & & & $\therefore$ & & & & & & & & & & & & . & 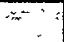 & $=$ \\
\hline Copper & & & & & & & & & & & & & & & & & & & $\bar{n}$ & & 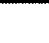 \\
\hline Cyanide & & & & & & & . & & & & & & & & & & & & & & $\therefore$ \\
\hline Hardness & & & & & & & $\therefore 3$ & & . & & & & & & & & & & & & \\
\hline Iron & : & & & & & & $\because \vdots$ & & & & & & & & & & & & $\mathbf{X}$ & $\mathbf{X}$ & $\mathbf{x}$ \\
\hline Lead & & & & & & & 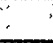 & & & & & & & & & . & & & & & \\
\hline Magnesium & & & & & & & $\because$ & & & & & & & & & & & & 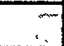 & & 7 \\
\hline Manganese & & & & & & & 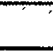 & $\therefore$ & & & & & & i & & $\mathrm{X}$ & $\mathbf{x}$ & $\bar{X}$ & $\mathbf{X}$ & $\mathrm{X}$ & $\bar{X}$ \\
\hline Mercury & & & & & & & $\because$ & $\therefore$ & & & & & & 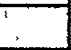 & & & & & $\therefore$ & & \\
\hline Nickel & minn & & & & & & $\cdots$ & & & & & & & & - & & & & 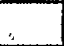 & & \\
\hline Nitrate & $\bar{X}$ & $\mathrm{X}$ & $\therefore$ & $\mathbf{X}$ & $\mathbf{X}$ & & $\mathrm{X}$ & $\bar{X}$ & $\because$ & $\mathbf{X}$ & $\mathbf{X}$ & & $\mathbf{X}$ & $\mathbf{X}$ & & & & & $\therefore$ & & \\
\hline Nitrate/Nitrite & & & $\mathbf{N}$ & & & $\mathbf{N}$ & $\because$ & $\therefore$ & $\because$ & & & & $\because$ & $\because$ & $\mathbf{N}$ & & & & 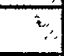 & & \\
\hline Potassium & . & & $\mathbf{0}$ & & & $\mathbf{0}$ & & $\therefore \ldots$ & 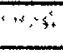 & & & & $\therefore$ & $\because$ & $\mathbf{0}$ & & & & $\therefore$ & 5 & \\
\hline Selenium & & & $\mathbf{N}$ & & & $\mathbf{N}$ & 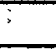 & $\therefore$ & & & & & $\therefore$ & $\because$ & $\tilde{N}$ & & & & $\therefore$ & & 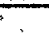 \\
\hline Silver & & & $\mathbf{E}$ & & & $\mathbf{E}$ & & 4 & 4.4 & & & & 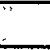 & & $\mathbf{E}$ & & & & & 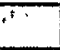 & \\
\hline Sodium & & & & & & & & & & & & & 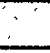 & & & & & & & & \\
\hline Thallium & & & & & & & & & & & & & 3 & & & & & & . & & \\
\hline Tin & $\therefore$ & $\cdots$ & & & & & 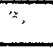 & $\therefore \therefore$ & $\therefore$ & & & & & & & & & &. & $\because$ & \\
\hline Vanadium & & & & & & & 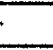 & & & & & & . & & & & & & & $\therefore$ & \\
\hline Zinc & & & & & & & & $\therefore$ & $\because$ & & & & & & & & & & & & \\
\hline
\end{tabular}


Table 13. Constituents in surface water whose $95 \%$ UCI exceeded 1989 measurements at one or more location along the F- and $\mathrm{H}$-Area seeplines and FMB, 1989-1997.

\begin{tabular}{|c|c|c|c|c|c|c|c|c|c|c|c|c|c|c|c|c|c|c|}
\hline Sample Date & \multicolumn{3}{|c|}{1992} & \multicolumn{3}{|c|}{ Feb 1993} & \multicolumn{3}{|c|}{ July 1993 } & \multicolumn{3}{|c|}{1994} & \multicolumn{3}{|c|}{1996} & \multicolumn{3}{|c|}{1997} \\
\hline Constituent & $F$ & $\overline{\mathbf{H}}$ & $\begin{array}{c}\mathbf{F} \\
\mathbf{M} \\
\mathbf{B}\end{array}$ & $\bar{F}$ & $\mathbf{H}$ & $\begin{array}{l}\mathbf{F} \\
\mathbf{M} \\
\mathbf{B}\end{array}$ & $\mathbf{F}$ & $\mathbf{H}$ & $\begin{array}{c}\bar{F} \\
\mathbf{M} \\
\mathbf{B}\end{array}$ & $\mathbf{F}$ & $\mathbf{H}$ & $\begin{array}{c}\mathbf{F} \\
\mathbf{M} \\
\mathbf{B}\end{array}$ & $\bar{F}$ & $\mathbf{H}$ & $\begin{array}{c}\mathbf{F} \\
\mathbf{M} \\
\mathbf{B}\end{array}$ & $\bar{F}$ & $\mathrm{H}:$ & $\begin{array}{l}\mathbf{F} \\
\mathbf{M} \\
\mathbf{B}\end{array}$ \\
\hline Alkalinity & & & $\bar{X}$ & & & & & & & & & & & & & & & \\
\hline Aluminum & $\mathrm{X}$ & $\overline{\mathrm{X}}$ & & $\bar{X}$ & $\bar{X}$ & $\bar{X}$ & & $\mathbf{N}$ & & $\mathbf{X}$ & & $\mathbf{X}$ & & $\bar{X}$ & $\mathbf{N}$ & $\overline{\mathbf{X}}$ & $\bar{X}$ & $\mathbf{N}$ \\
\hline Ammonia as $\mathrm{N}$ & & & & & & & $\therefore$ & o & & & & & & & 0 & & & $\mathbf{o}$ \\
\hline Antimony & & & & & & & & $\mathbf{N}$ & $\because$ & & & & ? & & $\mathbf{N}$ & & , & $\mathbf{N}$ \\
\hline Arsenic & & & : & & & & $\therefore$ & $\mathbf{E}$ & & & & & . & & $\mathbf{E}$ & & $\cdots$ & $\mathbf{E}$ \\
\hline Barium & & & & & & & $\because$ & $\because$ & $\therefore$ & & & & & & & & & \\
\hline Beryllium & & & & & & & $\ldots$ & $\cdots$ & 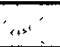 & & & & 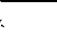 & & & & & \\
\hline Cadmium & & & & $\overline{\mathbf{X}}$ & & & $\mathbf{X}$ & $\therefore$ & - & $\mathbf{X}$ & & & & & & & & \\
\hline Chloride & $\mathrm{X}$ & $\bar{X}$ & $\mathrm{X}$ & $\mathbf{X}$ & $\bar{X}$ & & $X$ & $\therefore$ & 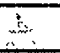 & & & & $\vdots$ & & & $\mathbf{X}$ & $X$ & \\
\hline Chromium & & & & & & & $\therefore$ & $y$ & $\therefore$ & & & & $\because$ & & & . & & \\
\hline Cobalt & & & & & & & $\therefore$ & $\therefore$ & 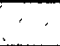 & & & & $\because$ & & & & & \\
\hline Copper & & & & $\bar{X}$ & & & $\mathbf{X}$ & & 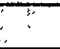 & & & & & & & & $\because$ & \\
\hline Cyanide & & & & & & & $\because$ & & & & & & . & & & & 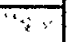 & \\
\hline Hardness & m & & 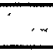 & $\mathbf{X}$ & & & $\div$ & $"$ & 3 & & & & $\sqrt{n^{3}}$ & & $\cdots$ & 5 & $\cdots$ & \\
\hline Iron & & & & & & & 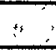 & & & & & & 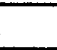 & & & & & \\
\hline Lead & & & & & & & $\therefore$ & & . & & & & $\therefore$ & $\therefore$ & & 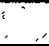 & . & \\
\hline Magnesium & & $\mathrm{X}$ & & & & & $\mathbf{X}$ & & $\because$ & & & & $\because$ & & & & & \\
\hline Manganese & & & & & & & & $\because$ & . & & & & $\because$ & $\because$ & & 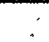 & $\therefore$ & \\
\hline Mercury & $\bar{X}$ & $x$ & $\mathbf{X}$ & & & & 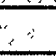 & $\therefore$ & $\therefore$ & & & & $\because$ & & & & $\cdots$ & \\
\hline Nickel & & & & & & & $\because$ & $\therefore$ & & & & & & & & & & \\
\hline Nitrate & & & $\because$ & & & & & $\mathbf{N}$ & & & & & & & $\dot{N}$ & & & $\mathbf{N}$ \\
\hline Nitrate/Nitrite & & & & & & & & 0 & & & & & & & 0 & & 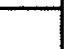 & $\mathbf{0}$ \\
\hline Potassium & & & , & & & & . & $\mathbf{N}$ & & & & & & & $\mathbf{N}$ & & $m$ & $\mathbf{N}$ \\
\hline Selenium & & & & & & & & $\mathbf{E}$ & & & & & & & $\mathbf{E}$ & & & $\mathbf{E}$ \\
\hline Silver & & & & & & & $\cdots$ & & & & & & & & & & & \\
\hline Sodium & & $\mathrm{X}$ & $\mathrm{X}$ & & $\mathbf{X}$ & & . & & $x$ & & & $\overline{\mathbf{X}}$ & & & & & & \\
\hline Thallium & $\div$ & & & & & & 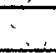 & $\because$ & & & & & & & - & & 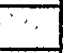 & \\
\hline Tin & & & & & & & $\ldots$ & $\therefore$ & & & & & & & & & & \\
\hline Vanadium & & & & & & & 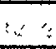 & & & & & & & & & & 5 & \\
\hline Zinc & 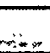 & $\mathrm{X}$ & $\therefore$ & & $\mathbf{X}$ & & $\bar{X}$ & 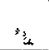 & 86 & & & & $\mathrm{X}$ & & & & & \\
\hline
\end{tabular}




\section{Appendix C}

F- and H-Area Seeplines and FMB Comparisons Against Region IV Standards, Background Concentrations, and 1989 Concentrations for Radionuclides 
Table 14. Radionuclides in surface water whose $95 \%$ UCI exceeded background measurements at one or more location along the F- and H-Area seeplines and FMB, 1989-1997.

\begin{tabular}{|c|c|c|c|c|c|c|c|c|c|c|c|c|c|c|c|c|c|c|}
\hline Sample Date & \multicolumn{3}{|c|}{1992} & \multicolumn{3}{|c|}{ Feb 1993} & \multicolumn{3}{|c|}{ July 1993} & \multicolumn{3}{|c|}{1994} & \multicolumn{3}{|c|}{1996} & \multicolumn{3}{|c|}{1997} \\
\hline Constituent & $\bar{F}$ & $\bar{H}$ & $\begin{array}{c}\mathbf{F} \\
\mathbf{M} \\
\mathbf{B}\end{array}$ & $\bar{F}$ & $\bar{H}$ & $\begin{array}{l}\mathbf{F} \\
\mathbf{M} \\
\mathbf{B}\end{array}$ & $\bar{F}$ & $\mathbf{H}$ & $\begin{array}{l}\mathbf{F} \\
\mathbf{M} \\
\mathbf{B}\end{array}$ & $\bar{F}$ & $\overline{\mathbf{H}}$ & $\begin{array}{c}\mathbf{F} \\
\mathbf{M} \\
\mathbf{B}\end{array}$ & $\bar{F}$ & $\mathbf{H}$ & $\begin{array}{c}\mathbf{F} \\
\mathbf{M} \\
\mathbf{B}\end{array}$ & $\bar{F}$ & $\mathrm{H}$ & $\begin{array}{l}\mathbf{F} \\
\mathbf{M} \\
\mathbf{B}\end{array}$ \\
\hline Americium-249 & & & & & & & & & & & & & & & & & & \\
\hline Cecium-137 & & & & & & & & & & & & & & & & & $\mathbf{N}$ & \\
\hline Cobalt-60 & & & & & & & & & & & & & & $\overline{\mathbf{X}}$ & & & $\mathbf{o}$ & \\
\hline Gross alpha & & & & & & & & & & & & & & $\overline{\mathbf{X}}$ & & $\bar{X}$ & $\mathbf{N}$ & \\
\hline Iodine-129 & & & & & & & & . & & & & & & & & & E & \\
\hline Nonvolatile beta & & & & & & & $\mathbf{X}$ & $\because$ & & & & : & $\bar{X}$ & $\mathbf{X}$ & & & & \\
\hline Radium-226 & & $\mathbf{X}$ & & & & & & & & & & & & & & & & \\
\hline Radium-228 & & & & $\overline{\mathbf{X}}$ & & & & & & & & & & & & & & \\
\hline Strontium-89 & & & & & & $n$ & & & $\therefore$ & & & & & & & & & $\therefore$ \\
\hline Strontium-90 & & & & & & & & & $\because$ & & & & a. & & . & & & $\therefore$ \\
\hline Technicium-99 & & & & & & x & & & & & & & 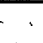 & & & & & $\%$ \\
\hline Tritium & $\bar{X}$ & $\mathrm{X}$ & & $\overline{\mathbf{X}}$ & $\mathbf{X}$ & & $\mathrm{X}$ & $\mathrm{X}$ & 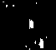 & $\bar{X}$ & $\bar{X}$ & & & & & & & \\
\hline Uranium-233/234 & & & & & & & & $\because$ & & & & & & & & & & 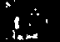 \\
\hline Uranium 238 & & & & & & $\because$ & & 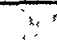 & 4 & & & $\%$ & & & 7 & & & \\
\hline
\end{tabular}

Note: FMB is N/A for this table since the comparison was not made. 
Table 15. Radionuclides in surface water whose $95 \%$ UCI exceeded PDWS, SDWS, or MCL at one or more location along the F- and H-Area seeplines and FMB, 1989-1997.

\begin{tabular}{|c|c|c|c|c|c|c|c|c|c|c|c|c|c|c|c|c|c|c|c|c|c|}
\hline Sample Date & \multicolumn{3}{|c|}{1989} & \multicolumn{3}{|c|}{1992} & \multicolumn{3}{|c|}{ Feb 1993} & \multicolumn{3}{|c|}{ July 1993} & \multicolumn{3}{|c|}{1994} & \multicolumn{3}{|c|}{1996} & \multicolumn{3}{|c|}{1997} \\
\hline Constituent & $\mathbf{F}$ & $\overline{\mathbf{H}}$ & $\begin{array}{l}\mathbf{F} \\
\mathbf{M}\end{array}$ & $\mathbf{F}$ & $\mathbf{H}$ & $\begin{array}{l}\mathbf{F} \\
\mathbf{M} \\
\mathbf{B}\end{array}$ & $\begin{array}{l}\mathbf{x} \\
\therefore \\
3\end{array}$ & $\mathbf{H}$ & $\begin{array}{l}\bar{F} \\
\mathbf{M} \\
\mathbf{B}\end{array}$ & $\begin{array}{c}\bar{F} \\
\bar{x}\end{array}$ & $\mathbf{H}$ & $\begin{array}{l}\mathbf{F} \\
\mathbf{M} \\
\mathbf{B}\end{array}$ & $\mathbf{F}$ & $\mathbf{H}$ & $\begin{array}{l}\overline{\mathbf{F}} \\
\mathbf{M} \\
\mathbf{B}\end{array}$ & $\bar{F}$ & $\bar{H}$ & $\begin{array}{l}\mathbf{F} \\
\mathbf{M} \\
\mathbf{B}\end{array}$ & $\bar{F}$ & $\mathbf{H}$ & \\
\hline Americium-249 & $\mathrm{X}$ & & & & & $\theta$ & & & & & & & & & & & & & & & \\
\hline Cecium-137 & & & & $\ldots{ }^{2}$ & & 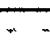 & & & $\mathbf{N}$ & 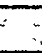 & & & & & & & & ? & & & \\
\hline Cobalt- 60 & & & & & & $\cdots$ & & & $\mathbf{0}$ & 7 & & & & & & & & & & & \\
\hline Gross alpha & $\mathbf{X}$ & $\mathbf{X}$ & & & $\mathbf{X}$ & & & & $\mathbf{N}$ & 4 & & & & & & & $\bar{X}$ & & & & \\
\hline Iodine- 129 & $\mathbf{X}$ & & & $\bar{X}$ & $\mathbf{X}$ & $\mathbf{X}$ & & & $\mathbf{E}$ & & & & & & & & & & & & \\
\hline Nonvolatile beta & $\mathbf{X}$ & $\mathbf{X}$ & $\mathbf{X}$ & $\bar{X}$ & $\mathrm{X}$ & $\mathbf{X}$ & & & & $\mathrm{X}$ & & $\because$ & & & & $\bar{X}$ & $\bar{X}$ & & $\bar{X}$ & $\mathbf{X}$ & \\
\hline Radium-226 & $\mathbf{X}$ & $\mathbf{X}$ & & & & & & & & & & & & & & & 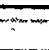 & $\because$ & & & \\
\hline Radium-228 & & & & $\bar{X}$ & $\mathbf{X}$ & $\mathrm{X}$ & $\overline{\mathbf{X}}$ & & & & & & & & & 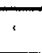 & & & & & \\
\hline Strontium-89 & $\mathbf{X}$ & $\mathbf{X}$ & & , & & & & & & . & & & & & & & (n & & & & \\
\hline Strontium-90 & $\mathbf{X}$ & $\mathbf{X}$ & & $\mathbf{X}$ & $\mathrm{X}$ & $\mathrm{X}$ & & & & & & & & & & $\mathbf{X}$ & $\mathbf{X}$ & & $\mathbf{X}$ & & $\mathbf{X}$ \\
\hline Technicium-99 & & & & & & & & & & $"$ & & & & & & & & & & & \\
\hline Tritium & $\mathbf{X}$ & $\mathbf{X}$ & $\mathbf{X}$ & $\bar{X}$ & $\bar{X}$ & $\bar{X}$ & $\bar{X}$ & $\mathbf{X}$ & & $\bar{X}$ & $\mathrm{X}$ & & $\mathbf{X}$ & $\mathrm{X}$ & $\bar{X}$ & $\bar{X}$ & $\bar{X}$ & $\mathrm{X}$ & $\mathbf{X}$ & $\mathbf{X}$ & $\mathbf{X}$ \\
\hline Uranium-233/234 & $\mathbf{X}$ & & & & & & & & & & & & & & & & & & & & \\
\hline Uranium 238 & $\mathbf{X}$ & & & & & & & & & & & & & & & & & 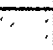 & & & \\
\hline
\end{tabular}

Table 16. Radionuclides in surface water whose $95 \%$ UCI exceeded 1989 measurements at one or more location along the F- and H-Area seeplines and FMB, 1992-1997.

\begin{tabular}{|c|c|c|c|c|c|c|c|c|c|c|c|c|c|c|c|c|c|c|}
\hline Sample Date & \multicolumn{3}{|c|}{1992} & \multicolumn{3}{|c|}{ Feb 1993} & \multicolumn{2}{|c|}{ July 1993} & & \multicolumn{3}{|c|}{1994} & \multicolumn{3}{|c|}{1996} & \multicolumn{3}{|c|}{1997} \\
\hline Constituent & & $\begin{array}{l}\mathbf{H} \\
\vdots \\
\vdots\end{array}$ & & & $\mathbf{H}$ & & $\begin{array}{l}\mathbf{F}_{1} \\
\vdots\end{array}$ & & & & & & & & $\begin{array}{l}\mathbf{F} \\
\mathbf{M} \\
\mathbf{B}\end{array}$ & & $\mathbf{H}$ & $\begin{array}{l}\mathbf{F} \\
\mathbf{M} \\
\mathbf{B}\end{array}$ \\
\hline Americium-249 & & $\because$ & & & & & $\therefore$ & & & & & & & & & & & \\
\hline Cecium-137 & & & $\bar{X}$ & & $\mathbf{N}$ & & & & & $\mathbf{N}$ & $\mathbf{N}$ & $\mathbf{N}$ & $\because$ & $\mathbf{N}$ & $\mathbf{N}$ & $\mathbf{N}$ & $\mathbf{N}$ & $\bar{X}$ \\
\hline Cobalt- 60 & & & & & $\mathbf{O}$ & & & & & $\mathbf{O}$ & $\mathbf{o}$ & $\mathbf{0}$ & $\because$ & $\mathbf{O}$ & $0^{\prime}$ & $\mathbf{O}$ & O & \\
\hline Gross alpha & & & & $\mathbf{X}$ & $\mathbf{N}$ & & & & & $\mathbf{N}$ & $\mathbf{N}$ & $\mathbf{N}$ & $\mathbf{X}$ & $\mathbf{N}$ & $\mathbf{N}$ & $\mathbf{N}$ & $\mathbf{N}$ & \\
\hline Iodine-129 & $\bar{X}$ & $\mathbf{X}$ & $\therefore$ & & $\mathbf{E}$ & & $\mathbf{X}$ & & & $\mathbf{E}$ & $\mathbf{E}$ & $\mathbf{E}$ & & E & $\mathbf{E}$ & $\mathbf{E}$ & $\mathbf{E}$ & \\
\hline Neptunium-237 & & & & & & $\mathbf{X}$ & & & & & & & & & & & & \\
\hline Nonvolatile beta & & & $\because$ & & & & " & & & & & & & & & & & \\
\hline Radium-226 & & & $\bar{X}$ & & & & 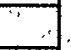 & & & & & & 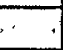 & $\therefore$ & $\because$ & & & \\
\hline Radium-228 & & & & & & & $\therefore$ & & & & & & & & : & & & \\
\hline Strontium-89 & & & & & & & & & & & & & & & & & & \\
\hline Strontium-90 & & & $\mathrm{X}$ & & & $\mathbf{X}$ & & & & & & & & & & & & \\
\hline Technicium-99 & & & & & & & & 3 & & & & & & & $\therefore$ & & & \\
\hline Tritium & - & & & & & & & & & & & & :- & & & & & \\
\hline Uranium-233/234 & & & & & & & & & & & & & & & & & & \\
\hline Uranium 238 & & & & & & & & & & & & & & & & & & \\
\hline
\end{tabular}


Appendix D

Statistical Discussion and Equations 


\section{Statistical Discussion}

\section{Analytical Results Omitted from Further Statistical Analyses:}

Results with an " $R$ " or a " $\mathrm{J}$ " qualifier were omitted from the statistical analyses. The " $R$ " code indicates the result should be rejected for use in estimating concentrations and determining change over time. Results coded with a "J" qualifier are estimated results. Six 1996 and no 1997 results were rejected due to an "R" qualifier. Considerably more results were omitted due to the "J" qualifier. In 1996, 130 results were omitted due to the "J" qualifier and in 1997, 161 results were omitted for the same qualifier. Of these, 17 in 1996 and 20 in 1997 were coded as estimated and less than the sample detection limit.

Duplicate samples were taken of some locations. Some of these were sent to the primary laboratory as blind (termed "field" duplicates) and some were sent to the secondary laboratory for confirmatory analyses (termed "split" duplicates). Neither laboratory was aware that they were analyzing duplicate samples. The results for the "split" duplicates from the secondary laboratory were not included in the statistical analyses. We did not want to confound the results with different laboratory detection limits, methods, and personnel. The "split" duplicates were used for confirmatory purposes only. The "field" and laboratory duplicate measurements were included, however. The primary laboratory for their quality control requirements conducted laboratory duplicate measurements. All results were reported. Also spiked results, and field, laboratory, and rinsate blanks were omitted. After omitting the 196 split duplicate results and the 128 spiked results for 1996 , there were 951 results remaining. For 1997, 168 split duplicate results and 212 spiked results were omitted, with 1,160 results remaining for the statistical analyses.

\section{Determination of Analytes with Results Above Detection Limits}

The first step was to determine how many analytes had at least one result above sample detection limits. In 1996 , there were 36 analytes with no results above detections in any of the 17 locations. There were 585 results for these 36 analytes. There were 29 analytes with at least 1 result above detection. There were 366 results for these 29 analytes. In 1997 there were 38 analytes with no results above detection. There were 639 measurements associated with these 36 analytes. The remaining 32 analytes had at least one result above detection. There were 521 measurements for these 32 analytes.

\section{Estimating Average Concentration per Sampling Location}

All of the statistical analyses were done using only the 366 (521 for 1997) results and only for the 29 (32 for 1997 ) analytes. Because there are laboratory and field duplicate measurements for many of the samples, the duplicate results for each sampling location and analytes were weighted to obtain a weighted estimate of the sample concentration for each location. First, all less than detection results were replaced by half the detection limit. For radionuclides, which could have less than detected results reported as negative or zero, half the method detection limit was used. This limit could vary from sample to sample. For the non-radionuclides, the reported result was the sample detection limit and was usually very consistent throughout the time period within analyte. The sample detection limit includes more than the method and instrument detection limit; it can include dilution and other factors. For the non-radionuclides, half the reported sample detection limit was used for those "less than detection" results.

\section{Method of Averaging laboratory and field Duplicate Measurements:}

(1) Results for laboratory duplicates were averaged. If $50 \%$ or more of the laboratory duplicates were above detection, then the laboratory average within sample was defined to be above detection. In 1996 there were 34 laboratory duplicate results and in 1997 there were 80 laboratory duplicate results among the analytes considered. 
(2) The laboratory averages found in step (1) were averaged over the field duplicates to get one average per each of the 17 sample locations. If at least $50 \%$ of the laboratory averages for each field duplicate was above detection, then the sample location average was defined as above detection. In 1996 there were 32 field duplicate samples for the 29 analytes and in 1997 there were 39 field duplicate samples for the 32 analytes.

Laboratory duplicate results can be used to estimate the laboratory measurement variability. Field duplicate results also measure laboratory measurement variability with some small component of sampling within the same location and at the same time included. However, this should be small compared with the laboratory variability. The advantage of the field duplicate measurements compared with the laboratory duplicate measurements is that the laboratory personnel are unaware that duplicate measurements on the same sample are being made. Laboratory personnel may be very much aware of which samples are laboratory duplicates. Split duplicates also measure laboratory measurement variability similar to field duplicates except that it is a different laboratory, different personnel and sometimes different methods. Because of this added difference, split duplicate results were omitted. Since the laboratory duplicate results should demonstrate the least variability, they were averaged first. The field duplicate results measure much the same variability as the laboratory duplicates but without laboratory personnel knowledge. The field duplicate averages were next averaged to get one average concentration per sampling location and analyte. Each sampling location is assumed to be an independent sample from the population area. The FSP samples identify one general area, the HSP samples another, and the BG samples a third. The three FMC seepage samples (FMC001F, FMC001H,

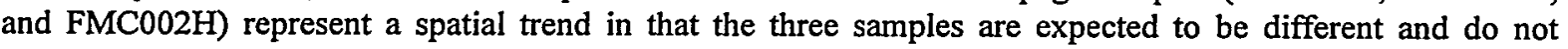
represent an independent sample of the entire seepage stream.

\section{Statistical Estimates}

After averaging the results in step (1), there were 332 laboratory averages for the 29 analytes in 1996 . (For 1997 there were 441 laboratory for the 32 analytes.) After the step (2) averaging there were 300 sampling events for the 29 analytes (1996) and 402 sample averages for the 32 analytes (1997). Each sampling location within FSP, HSP, or BG represents an independent measurement of the average concentration for the area. Eq. (1) represents the statistical model for the FSP, HSP, and BG measurements for each analyte-a. Let $X_{i}$ (a)be the ith measurement for analyte-a for one of the three areas. There were at most five sampling locations for FSP and HSP, and four sampling locations for BG. Let $\mathrm{n}(\mathrm{a})$ be the number of sampling locations sampled for analyte-a, and $X_{1}(a)$ be the true average concentration over the area for analyte-a. Then the difference between $X_{i}(a)$ and $X_{t}(a)$ is termed the error term and includes laboratory and sampling errors or variability. It can also include reporting and transcribing errors. The error term $\varepsilon_{i}(a)$ is generally assumed to be normally distributed with zero mean and variance $\sigma^{2}(a)$.

$$
X_{i}(a)=X_{t}(a)+\varepsilon_{i}(a)
$$

The sample mean and variance estimate the true concentration and the laboratory and sampling variance component. The sample mean is computed using Eq. (2) and the sample variance by Eq. (3). Sometimes the -error terms or the measurements are considered to be lognormally distributed. In this case, the results are transformed by taking the natural logarithm of the location average and the sample means and variances computed using the natural logarithms. The sample mean is computed using

$$
\bar{X}(a)=\sum_{i} X_{i}(a) \div n_{i}(a)
$$

The sample variance is computed using 


$$
S^{2}(a)=\sum_{i}\left(X_{i}(a)-\bar{X}(a)\right)^{2} \div\left(n_{i}(a)-1\right.
$$

\section{Comparison of FSP and HSP Average with Background Average:}

The averages for FSP and HSP were compared with the background (BG) average. Two methods were used. The first method is to compare the two averages using a two-sample t-test based on the natural logarithms of the results. This is equivalent to a one-way ANOVA test with two contrasts. However, the ANOVA test assumes equal variances for both FSP (HSP) and BG and also will not indicate the direction of the difference. The two-sample t-test was done using SAS $\otimes$ PROC TTEST. The sample estimates of mean and variance for each of the three areas, FSP, HSP, and BG were computed using eqs. (2) and (3) on the natural logarithms of the results. The two variance estimates were compared using a folded F-statistic (ratio) as given in Eq. (4). The two variances are FSP and BG or HSP and BG. The larger variance is to go in the numerator and the smaller variance in the denominator. The folded F-statistic is equivalent to a two-tailed F-distribution ratio. Let $\mathrm{L}$ indicate the larger variance and $S$ the smaller variance, then the $F$-ratio of concern is

$$
F^{\prime}=S_{L}^{2}(a) \div S_{S}^{2}(a)
$$

If the probability of getting a larger ratio is greater than 0.05 , conclude there is no evidence of a difference in variability between FSP (HSP) and BG samples. If the probability is less than 0.05 , then the differences in variability are assumed to be significant. The variances were compared by computing the variance on the untransformed results (results as concentrations) and the natural logarithms of the results. In almost all cases, the folded F' statistic indicated significant differences in variability between background and FSP or HSP. When the same ratio comparison was made using natural logarithms, only magnesium and nonvolatile beta for FSP and cobalt-60, gross alpha, and nonvolatile beta for HSP indicated significant differences for 1996. For 1997 the significant differences were gross alpha and magnesium for FSP and copper and magnesium for HSP.

The two-sample t-test to test for significant differences in means depends on whether the variances are assumed equal or unequal. If the variances are assumed equal, a pooled variance estimate is made. This is given in Eq. (5). The degrees of freedom are equal to $\left(\mathrm{n}_{\mathrm{b}}+\mathrm{n}_{\mathrm{F}}-2\right)$.

$$
S_{p}^{2}=\frac{\left(n_{B}-1\right) S_{B}^{2}+\left(n_{F}-1\right) S_{F}^{2}}{\left(n_{B}-1\right)+\left(n_{F}-1\right)}
$$

The variance for the difference between BG and FSP (HSP) is computed using Eq. (6).

$$
S_{d}^{2}=\sqrt{\frac{S_{p}^{2}}{n_{B}}+\frac{S_{p}^{2}}{n_{F}}}
$$

When the variances were significantly different, the variance for the difference was computed using Eq. (7). Satterthwaite's approximation is used for the degrees of freedom for the approximate t-ratio.

$$
S_{\mathrm{d}}^{2}=\sqrt{\left(\frac{S_{\mathrm{B}}^{2}}{\mathrm{n}_{\mathrm{B}}}+\frac{S_{\mathrm{F}}^{2}}{\mathrm{n}_{\mathrm{F}}}\right)} .
$$


The t-test ratio is computed using Eq. (8) and then is compared with the Student's $t$ distribution with the appropriate degrees of freedom to get a two-tailed probability of a difference between BG average concentration and FSP or HSP average concentration. It may be more appropriate to use a one-tailed probability and only when the FSP or HSP average concentration exceeded the BG average. For a one-sided probability divide the stated probability by 2 .

$$
t-\text { ratio }=\frac{\left|\bar{X}_{B}-\bar{X}_{F}\right|}{S_{d}}
$$

In Table2 and 3 the FSP and HSP averages are compared with the BG average. The first part of Tables assumes the measurements are lognormally distributed and compares the difference using the t-ratio with the probability given of getting a bigger absolute ratio. The actual signed $t$-ratio is given with the twotailed probability of getting a bigger ratio. The second part uses the Mann-Whitney-Wilcoxon two-sample statistic to compare with the FSP and HSP samples with the background samples.

For the two contrast problem, the statistical model for the Mann-Whitney-Wilcoxon assumes that the probability functions for the populations are identical in form and shape, including the variance and all other parameters, but are shifter apart by a quantity that represents the difference between two location parameters, for examples population medians or means. The test is primarily sensitive to differences in medians.

For the Mann-Whitney-Wilcoxon test, the usual assumptions are that the two variables (background and FSP or HSP concentrations) come from a population distributions that are the same. Assume the cumulative population distribution functions are $F_{B}$ and $F_{F S p}$. The null hypothesis is stated in Eq. (9).

$$
F_{B}(u)=F_{F S P}(u) \text { for all possible values of } u \text {. }
$$

If $M_{B}$ denotes the true median of the background population and $M_{F S P}$ the true median of the FSP or HSP population then the null and two-sided alternative hypothesis can be stated as:

$$
H_{0}: M_{B}=M_{F S P} \quad H_{a}: M_{B} \quad M_{F S P}
$$

The sample concentrations for both BG and FSP or HSP are arranged in a single ordered sequence, either from smallest to largest or largest to smallest. The first value in the sequence is assigned the rank of 1 , the next one assigned the rank of 2, etc. to the last one is assigned the rank of $n_{B}+{ }_{n F}=N$.

The Mann-Whitney-Wilcoxon test statistic is defined as

$$
T_{B}=\text { sum of the background ranks or alternatively } T_{F}=\text { sum of the FSP ranks. }
$$

These two values are related by

$$
\mathrm{T}_{\mathrm{B}}=(\mathrm{N} \div 2)(\mathrm{N}+1)-\mathrm{T}_{\mathrm{F}}
$$

The null sampling distribution of $T$ is symmetric about its mean value which is $m(N+1) / 2$ where $m$ is the number of sample points in the rank sum. Thus, the left-tail cumulative probability is equal to the corresponding right-tail probability. Most tables give the probability for the smaller size sample and for only small combinations of group sizes. For larger sample sizes, the sampling distribution can be approximated by the asymptotic distribution, which is the normal distribution for standardized $\mathrm{T}$. The approximation usually incorporates a continuity correction of 0.5 . 
Two or more observations that are equal are called "tied". Ties may occur between observations in the same sample or in different samples or both. Since the populations are assumed continuous, the probability of a tie, either within or across samples, is zero. In reality measurements are not strictly continuous especially when detection limits are used for values less than detection. The midrank method is used to assign the ranks to the tied values. However, the exact null distribution of $T$ is not the same when ties are present. The usual procedure in small samples is to use this distribution anyway, unless there are many ties. When the normal approximation is used, a correction for ties can be incorporated.

The SAS@ procedure NPARIWAY was used to compare the background median with the FSP or HSP median. SAS handles ties by assigning the average rank score to all the tied values. Adjustments to the variance estimates are performed in the manner described by Hajek (1969, Chapter 7). The procedure computes the probability of a larger difference using the Z-scores with a continuity correction and then compares the Zscores using a t-test. The $Z$-scores include the variance adjustment for ties.

The results presented in Table 2 and 3 include the sum of the ranks for the group with the smaller number of samples and the two-tailed t-test approximate probability.

Making a number of different comparisons to determine whether FSP or HSP is significantly different from the background increases the chance of finding at least one significant difference due to chance and not due to a real difference. One method of accounting for this is to adjust the individual difference so that the entire set of comparisons will show no significant differences with probability 0.95 when there are no differences. The Boniferroni method can be used to adjust the individual comparison probability trigger of 0.05 by dividing by the number of comparisons, n. For FSP there are approximately 9 legitimate comparisons and for HSP 11. (By legitimate is meant that the majority of the results are above detection). The individual probability triggering significance is $0.05 / 11=0.0045$ and $0.05 / 9=0.0056$. (For 1997 there are 15 legitimate comparisons for both FSP and HSP. So the triggering probability for significance on an individual comparison is $0.05 / 15=0.0033$.) That is, declare any one BG-FSP contrast significant if the probability is less than 0.0056 or BG-HSP significant if the probability of a greater difference is less than 0.0045 . This adjustment is valid for both the $t-$ test on the natural logarithm contrasts and for the Mann-Whitney-Wilcoxon rank sum contrasts. Since two different tests are used, this also increases the chance of finding a significant difference when, in fact, none exists. Suggest determining significant differences using only the t-test on the natural logarithms and the MannWhitney-Wilcoxon test as only confirmation of the significant difference. For 1996, this would mean a significant difference for gross alpha for FSP and none for HSP using the natural log transform contrasts. No significant differences would be declared using the Mann-Whitney-Wilcoxon probabilities. Note these are not as sensitive in picking up differences as the first test. However, when differences are picked up they will generally also be picked up using the ANOVA or t-test also. For 1997 the significant contrasts would be tritium and nitrate-nitrite as nitrogen for HSP and none for FSP using the t-tests and natural log transforms. Again no contrasts would be declared significant using the Wilcoxon rank sum test.

\section{Comparisons with 1989 Concentrations and Standards:}

The 1989 sampling event did not sample at all of the locations sampled in 1996 (1997). There is no estimate of measurement and sampling variability and thus no probability of whether the observed difference is significant. Only differences where the 1996 (1997) result is above detection should be counted as a difference in the sample values. There are 4 differences when the 1996 result is above detection. There is one each for aluminum, gross alpha, iodine-129, and zinc. Two occurred at sample location HSP043 and two at location FSP012. For 1997 there are six differences. These are two for aluminum, three for chloride, and one for cesium-137. The cesium-137 difference occurred in one of the seepage locations, FMC002H, while all other differences occurred in either the FSP or HSP series. FSP047 had two differences, HSP043 had two differences and FSP204 had one difference. 
Comparing the 1996 results for the 29 analytes with the EPA human health standard values, there is no estimate of measurement and sampling variability and no probability of whether the observed difference is significant. Only those sample values above detection should be considered as an indication of a difference. Measurements less than detection that exceed the standard indicate the analytical method is not sensitive enough to detect a difference equal to the standard. For 1996 all but one of the thallium differences were due to the less than detection sample limit. It is apparent that manganese, non-volatile beta, strontium-90, and tritium have a majority of sample locations exceeding the standard for at least one of the areas (BG, FSP, HSP, or FMC). Gross alpha and iodine-129 had 2 out of the 3 available HSP samples exceeding the standard. For 1997, no less than detected results exceeded the standard since all of the thallium results for all sample locations were less than detected and didn't make it to this comparison. The majority of sampling locations exceeded the standard for iron, manganese, and tritium. Strontium-90 only had 1 location with a measurement for FMC and FSP and these exceeded the standard.

If the 1996 result was less than detection and exceeded the 1989 or standard, there is no guarantee the actual result exceeds the comparison value. Whenever the 1996 result is less than detection, the comparison is of no interest but has been reported indicating that the laboratory detection limits are not sufficiently small to permit reliable detection of significant differences. The results reported at less than detection have a " $U$ " in the qualifier column and the results are half the detection limit. 